\title{
The Latin Poems of Margareta van Godewijck (1627-1677)
}

\author{
ARON OUWERKERK
}

This contribution presents the editio princeps of all extant Latin poems written by the Dutch poet Margareta van Godewijck from Dordrecht. In order to increase the accessibility of these hitherto unpublished texts, the edition is preceded by an extensive preparatory analysis of previous biographical sources and accounts of how her poems were received. These will illustrate the need for the present study. There follow an evaluation of her Latin poems with regard to both form and content and a discussion of her Latinity, textual interaction with other Neo-Latin poets, and the literary merits of her work. It is argued that her Latin poetry had a clear social and performative function and can best be considered within the context of student composition. Finally, an account of the trajectories of the two surviving autographs and an explanation of the editorial principles prepare the reader for the critical edition.

\section{Introduction}

Paris, 22 January 1828. At an auction of the library of Louis-MarieJoseph Duriez, a member of the Société des bibliophiles français, two manuscripts had drawn the attention of a traveler.* Thought for a long time to have been lost forever, these items were now catalogued together as Margaretae Godeviciae Poemata latina, gallica et belgica ("Latin, French and Dutch poems by Margareta van Godewijck"). ${ }^{1}$ Until then, little had remained of the poetic oeuvre of Van Godewijck, a learned woman from the mid-seventeenth century who had earned a reputation during her own lifetime as "the pearl of Dordrecht". ${ }^{2}$ Some hundred and

* I would like to express my gratitude to the Editorial Board of $H L$, in particular to Dirk Sacré, for their invaluable advice on the manuscript. I am also indebted to the help and support that I received from David Rijser, Theodore Delwiche, and Margreet Lefeber-Karres.

1 Catalogue des livres imprimés et manuscrits, composant la bibliothèque de feu M.L.-M.-J. Duriez (de Lille) (Paris, 1827), 213, no. 2182.

2 As is common for names from this period, one can find different spelling variations for Margareta van Godewijck. She herself often wrote her name as Margareta Godewyk, but also used the forms Margarita, Marguerite, and Godevicia. In the secondary literature, her first name is often spelled Margaretha, her family name sometimes as Van Godewyck. She was described as "the pearl of Dordrecht" by Matthijs Balen, Beschryvinge der stad Dordrecht (Dordrecht, 1677), 203. A pun is intended, as the Latin word for 'pearl' is margarita. 
fifty years had passed, and the memory of her work at the turn of the nineteenth century was mainly based on only a handful of contemporarily published poems and a brief biography that one of her friends, Matthijs Balen, had included in his monumental Beschryvinge der stad Dordrecht in the year she died. ${ }^{3}$

Yet, that Tuesday in 1828, her fortune was about to change. Johannes Immerzeel Jr. (1776-1841), a passionate writer, poet, bookseller and publisher, acquired two autographs of Van Godewijck and brought them with him from Paris to the Hague. ${ }^{4}$ It was soon after their repatriation, that he assured the members of his close network with a printed note saying that:

One may expect from the present owner of these manuscripts, being so important to the history of arts and to the glory of his own city of birth [sc. Dordrecht], that he himself will inform his poetryloving compatriots in an appropriate fashion by means of the press. ${ }^{5}$

The recovery of the manuscripts thus created high expectations among the local and national intelligentsia. During the ensuing decades, several treatises on Van Godewijck's life and work appeared, as the autographs were shared and lent by an elite, patriotic, and art-loving community. ${ }^{6}$ Finally, around 1900, both manuscripts came into the possession of the local archive of Dordrecht, Regionaal Archief Dordrecht, now catalogued as ms. 1024 and ms. 1025 (henceforth: ms. 1024 and ms. 1025). ${ }^{7}$

Despite the relatively early interest in and renown of Van Godewijck, the promise made soon after the rediscovery of her manuscripts in $1828-$ that there would be a printed edition of her work - has never been fully

3 Ibid.

4 G.D.J. Schotel (ed.), Letter-en oudheidkundige avondstonden (Dordrecht, 1841), 88. On Immerzeel, see A.J. van der Aa (ed.), Biographisch woordenboek der Nederlanden (Haarlem, 1852-1878) [henceforth: $B W N$ ], vol. 9, 18-20.

5 Broadsheet, [s.l.a.], attached to the cover of Dordrecht, Regionaal Archief Dordrecht, ms., archief 150: Collectie van Handschriften, no. 1024 [henceforth: ms. 1024]. Unfortunately, the author and publisher of this printed note remain anonymous. The text nevertheless makes clear that Immerzeel is still the owner of the manuscripts. All translations in this article are mine.

6 Schotel 1841 (as in n. 4), 45-119; A.C. Loffelt, "Een Hollandsche juffer in de zeventiende eeuw", Nederland 3 (1876), 91-116; H. Collot d'Escury, Hollands roem in kunsten en wetenschappen, vol. 4.2 (Den Haag, 1830), 161-162.

7 Ms. 1024; Dordrecht, Regionaal Archief Dordrecht, ms., archief 150: Collectie van Handschriften, no. 1025 [henceforth: ms. 1025]. 
realized. In addition, a considerable part of her work, although often mentioned, is consistently underplayed in the discussions of her life and poetry (see the discussion in section 3). In part, this oversight can be traced back to her most authoritative biographer, the famous preacher and literary historian Gilles Schotel (1807-1892), who had only ms. 1024 at his disposal. ${ }^{8}$ Consequently, his influential and still frequently quoted biography rather unfortunately left ms. 1025 out of the discussion.

Another, more recent reason for the exclusion of ms. 1025, lies in the nature of the poems it contains, which makes them a rarity even within the specialized field of women's literature of the Dutch Republic today: whereas ms. 1024 contains chiefly vernacular poems in Dutch, the poems in ms. 1025 are all composed in Latin. This fact constitutes the raison d'être of the present critical edition. It provides the studia Godeviciana with the first critical opera omnia edition of her Latin poetry, encompassing all poems present in ms. 1025 and the few Latin poems that are included in ms. 1024. First, however, an introduction is provided to characterize both Van Godewijck's life and her work historically. This is followed by a brief discussion on the secondary literature that has engaged with her literary output. The subsequent analysis of Van Godewijck's Latin oeuvre will not only discuss matters of style, but also position specific (groups of) poems in their relevant socio-historical context. Finally, a historical account of the two autographs containing Van Godewijck's Latin poetry and some editorial notes will elucidate the ratio edendi of the present edition. It is hoped that this critical edition will give rise to a more inclusive appreciation and understanding of the literary oeuvre and agency of this accomplished woman.

8 Schotel 1841 (as in n. 4), 51. Later, Schotel published another treatise on Van Godewijck, Margaretha van Godewyck ([s.1.], [ca. 1863]). This second study is significantly shorter and less well documented, and does not really contribute to the first. It has therefore played no role in the secondary literature either. 


\section{Biography}

Margareta van Godewijck was born on 31 August 1627 as the daughter of Pieter Govertsz van Godewijck and Sara Cornelisdr Pijpelaar. ${ }^{9}$ Throughout her whole life, she lived in Dordrecht, a city brimming with economic, religious and literary abundance, in part due to the growing imperial ambition and the expanding economy in the wider Dutch Republic. Her father, Pieter van Godewijck (1593-1669), was a locally well-known and respected schoolmaster, who in his spare time wrote poetry (most of it in vernacular) and was also interested in Dordrecht's local history. ${ }^{10}$ As a schoolmaster at the local grammar school, he ensured his daughter received an excellent education, which also included his own passion for verse composition. This way, the young Van Godewijck grew up in an environment that encouraged her ambition to learn, and when she was only fifteen years old, her father felt confident to include some of her Dutch poems in his publications. ${ }^{11}$

Although most of her writings are in Dutch, this was not the only language that Van Godewijck learned. Besides Dutch, she knew how to read ancient Greek at least at the level of the New Testament. Allegedly, she also mastered Hebrew, Italian and English, but none of her writings in

9 There is a persistent tradition that spreads doubt whether Van Godewijck was born/baptized on 30 or 31 August 1627. The baptism register book of the Augustijnenkerk of Dordrecht only mentions the month August; Dordrecht, Regionaal Archief Dordrecht [henceforth: RAD], ms., archief 11: Doop-, trouw- en begraafboeken van Dordrecht, no. 4, f. 79v. I did not find any mention of the $30^{\text {st }}$ prior to Schotel's biography; Schotel 1841 (as in n. 4), 45. Van Godewijck's friend, the local historian Matthijs Balen, writes that she passed away on 2 October 1677, "at the age of 50 years, 2 months and 2 days"; Balen 1677 (as in n. 2), f. Nnnnnnnn3-r. He also included an engraving of her that includes the text: "Nata Aug 31: 1627"; ibid, 203. Therefore, it seems likely that the confusion started only after Schotel's inaccurate mention in 1841.

10 His best known work is Witte-broods kinderen, of bedorve jongelingen. Bly-eynde spel (Dordrecht, 1641). His historical work was never published during his lifetime, but was consulted by Matthijs Balen for his Beschryvinge; Balen 1677 (as in n. 2). His manuscript has been diplomatically edited by W.M. van der Schouw (ed.), Dese heerlicke Stad. Een zeventiende-eeuws kroniek van Dordrecht door Pieter Govertsz. van Godewijck (1593-1669) (Dordrecht, 2006). The most extensive biographical work on Pieter van Godewijck is still the one by Schotel 1841 (as in n. 4), 123-135.

11 To my knowledge, these early poems have hitherto remained unidentified as having been published. They can be found in Pieter van Godewijck, Lof-gedicht, voor den edelen, erntfesten, achtbaren en seer discreten heer Mr. Iacob van Beveren, heeren Cornelisz (Dordrecht, 1643 [USTC 1024859]), f. A3v; and id., Klaegh-reden op het droevigh afsterven van den God-saligen en seergheleerden D. Nicolaus Crucius (Dordrecht, 1643 [USTC 1450003]). These poems can be found in unpublished form in ms. 1024, p. $58-59,60-61$. 
these languages is extant. ${ }^{12}$ We are, however, better informed about her knowledge of French and Latin, languages she came to master so well that she could write poetry in it, witness not only her manuscripts, but also a handful of occasional poems that found publication in books from both her father and close family friends, most notably the already mentioned Matthijs Balen and Lambert van den Bosch (Lambertus Sylvius). ${ }^{13}$

For young women, writing poetry was not at all an uncommon practice in the early modern period, and was often even "considered part of elite household pastime and cultural refinement". ${ }^{14}$ Van Godewijck's case, however, is slightly more unusual and requires more contextualization in order to appreciate its historical, socio-cultural significance. NeoLatinists have for a long time been prone to stress the "fundamentally democratic" and "universal" aspects of early modern Latinity, where "everyone had the same chances, as everyone had to make the same effort, namely to learn Latin". ${ }^{15}$ This, indeed, is true for a euro- and an andro- and aristocentric point of view. In the context of the Netherlands, however, Latin and Greek high-school education became institutionally accessible to women only gradually after 1880 (and this is not drastically different from the rest of Europe). ${ }^{16}$ Therefore, classical education, which was regarded as an almost essential foundation for higher learning and literary productivity, was rather a fundamental impediment, which relatively few women were able to overcome. ${ }^{17}$ Sometimes, if a father decided to educate his sons at home, the daughters were able to benefit

12 Balen 1677 (as in n. 2), 203.

13 On Van den Bosch, see $B W N$, vol. 2, 978-980.

14 M. van Elk, Early Modern Women's Writing. Domesticity, Privacy, and the Public Sphere in England and the Dutch Republic (Basingstoke, 2017), 8.

15 J. IJsewijn, “Overdenkingen bij het (Neo-)Latijn”, Hermeneus 65.3 (1993), $55-59$, at 58.

16 P.Th.F.M. Boekholt, E.P. de Booy, Geschiedenis van de school in Nederland vanaf de middeleeuwen tot aan de huidige tijd (Assen - Maastricht, 1987), 190-193. For a broader account of the exclusion of women from classical education, see F. Waquet, Latin or the Empire of a Sign (London - New York, 2001), 223-226; D. Van Miert, "Contested cultural citizenship of a virtual transnational community. Structural impediments for women to participate in the Republic of Letters (1400-1800)", in R. Buikema, A. Buyse, A.C.G.M Robben (ed.), Cultures, Citizenship and Human Rights (London, 2019), 196-214, at $200-201$.

17 Cf. C. Maas, "Hadrianus Junius' Batavia and the Formation of a Historiographical Canon in Holland", in D. van Miert (ed.), The Kaleidoscopic Scholarship of Hadrianus Junius (1511-1575). Northern Humanism at the Dawn of the Dutch Golden Age (Leiden, 2011), 38-68, at 43-46. 
from their brothers' schooling and could learn Latin as well. ${ }^{18}$ In other cases, fathers were professional educators themselves and taught their daughters at home, or asked befriended colleagues to do so. ${ }^{19}$

Indeed, for Van Godewijck, her father's profession ensured the essential classical knowledge. Some have also claimed that she studied with Johannes Rampius, a colleague of her father and the headmaster of the Latin school in Dordrecht. ${ }^{20}$ The evidence for this, however, seems to solely rely on a single poem that she wrote to him in September 1654, which includes the lines: "your tongue of nectar raised my youth, / your school of wisdom made me speak Latin fluently". ${ }^{21}$ Although this may, admittedly, seem a clear indication of Rampius' involvement in Van Godewijck's education, it is crucial to realize that this is poetry; the socalled lyric voice in the poem should not immediately be identified with the historical author. In fact, at the beginning of the poem, she wrote expressis verbis "Dordrecht spreekt" ("Dordrecht speaks"), a clear indication that we are dealing with a different voice, presumably from the youth of Dordrecht. Moreover, the line mentioning Rampius' "school of wisdom" would cause interpretational problems if understood as pertaining to the real Van Godewijck. After all, she was never a real student at his Latin school.

While Rampius' involvement in Van Godewijck's education will likely remain a matter of debate, the alleged role of Isaac Beeckman (1588-1637), a friend of Descartes, should be debunked. ${ }^{22}$ This claim seems to be based on a plain misreading of Schotel's 1841 biography,

18 H. Parker, "Women and Humanism. Nine Factors for the Woman Learning", Viator (2004), 581-616, at 601; J. Stevenson, "Women's Education”, in P. Ford, J. Bloemendal, C. Fantazzi (ed.), Brill 's Encyclopaedia of the Neo-Latin World, vol. 1 (Leiden - Boston, 2014), 87-99.

19 Parker 2004 (as in n. 18), 598-601; J. Stevenson, Women Latin Poets. Language, Gender, and Authority from Antiquity to the Eighteenth Century (Oxford, 2005), 154, 328, 341-342, 391; Stevenson 2014 (as in n. 18).

20 The first to mention this was Schotel 1841 (as in n. 4), 49. His claim has been copied in almost all the secondary literature that mentions Van Godewijck; see $B W N$, vol. 7, 232; C.L. Thijssen-Schoute, "Een correspondent van Descartes. Andreas Colvius", Nederlands archief voor kerkgeschiedenis 38 (1952), 224-248, at 233; J. Stevenson, "The Emblem Book of Margareta Van Godewijck (1627-1677)", in A. Saunders, P. Davidson (ed.), Visual Words and Verbal Pictures. Essays in Honour of Michael Bath (Glasgow, 2005), 161-201, at 162-163; Stevenson 2014 (as in n. 18), 96.

21 "U Nectar tong die deed mijn jeugt opqueeken, / U Wysheits School 't Latijn ook suver spreken"; see ms. 1024, p. 284.

22 Stevenson 2005 (as in n. 20), 162; Stevenson 2014 (as in n. 18), 96. 
who wrote that Beeckman had been her father's teacher. ${ }^{23}$ As a matter of fact, Schotel's statement is dubious as well. Beeckman was only five years older than Pieter van Godewijck. Moreover, we know that Pieter van Godewijck studied nowhere else than at the Latin school in Dordrecht, where he already became a teacher himself in 1619, while Beeckman only came to this city in $1627 .{ }^{24}$

It is thus safest to say that Van Godewijck was educated by her father. He ensured the essential classical knowledge and enabled a fruitful literary engagement with her contemporaries. This way, Van Godewijck maintained contact with many well-known citizens from Dordrecht, who hailed her as a miracle of her sex. Since the early Renaissance in Italy, high-educated women like Battista da Montefeltro (1383-1450), Laura Cereta (1469-1499), and Olimpia Morata (1526-1551) had become icons of the socio-cultural sophistication of their family, state and age. ${ }^{25}$ Hence, a stereotype for learned maidens arose in Europe, which was also fueled by the exemplary literature on women that was being written in the wake of Boccaccio's widely read De mulieribus claris (1362). ${ }^{26}$ For Van Godewijck and her contemporaries, this stereotype was above all embodied by the internationally renowned Anna Maria van Schurman (1607-1678), with whom she not only was compared by others, but also compared herself (as inferior) in her poems. ${ }^{27}$

Similar to Van Schurman and the fashionable role of female prodigy, Van Godewijck's talent for language and literature was not the only means through which she acquired renown. Besides writing verse, she was also skilled in the arts and crafts that were often practiced by women with more leisure time, such as paper cutting, embroidering, glass engraving, playing the harpsichord, and painting. The 28 paintings that accompany her emblem poems in ms. 1024, however, have been criticized by

23 Schotel 1841 (as in n. 4), 48.

24 Ibid., 123-124; K. Van Berkel, "Isaac Beeckman 1588-1637," in A.J. Kox (ed.), Van Stevin tot Lorentz. Portretten van achttien Nederlandse natuurwetenschappers (Amsterdam, 1990), 20-33, at 23.

25 Cf. J. Stevenson, "Women Prodigies. Anna Maria van Schurman, Elena Piscopia and Others", in P. Ford, J. Bloemendal, C. Fantazzi (ed.), Brill 's Encyclopaedia of the Neo-Latin World, vol. 2 (Leiden - Boston, 2014), 1199; H. Parker, "The Magnificence of Learned Women", Viator 38 (2007), 265-289.

26 V. Brown (ed., tr.), Giovanni Boccaccio, Famous Women (Cambridge, MA London, 2001), xx-xxii.

27 Balen 1677 (as in n. 2), 203. Van Godewijck mentions Van Schurman's name in poem IXb, 12 of the present edition, and in her Dutch work in ms. 1024, p. 182, 238. She might have met her, although there is no direct evidence to support this assumption. 
many as "show[ing] no knowledge of anatomy and a highly limited technique", although it is acknowledged that they should rather be regarded as snapshots of her youthful skills and therefore not necessarily indicative of her later work. ${ }^{28}$ Her self-portrait in Indian ink (see fig. 1), for example, certainly shows some artistry, as do the photocopies of Van Godewijck's genre paintings that have survived, but whose location, unfortunately, remains unknown. ${ }^{29}$

Through her artwork and poetry, and with the help and support of her father, Van Godewijck was thus able to gain prominence amongst her contemporaries. The fundamental and formative role of Pieter van Godewijck ceased, however, after his death in 1669. Van Godewijck now had to continue her socio-literary life without her father's role. This might have been a factor in the apparent downturn of Van Godewijck's literary production between roughly 1663 and 1677, as her father's death signified the end of his mentorship, and likely led to less financial security and more obligations in the household she shared with her mother. ${ }^{30}$ Based on what has come down to us, she wrote only a handful of short occasional poems around 1677 that were intended for publication. Amongst them were two Latin poems (poem XXIb and XXIIb of the present edition) that she also copied in a remarkably shakier hand at the end of ms. 1025, in a clear attempt to complement, complete and preserve her largely handwritten oeuvre for later generations. ${ }^{31}$ She died unmarried on 2 October 1677 , at the age of $50 .{ }^{32}$

28 Stevenson 2005 (as in n. 20), 161-201, at 167, 169. The best description of Van Godewijck's extant handiwork and its present-day existence can be found in E. Oosterlinck, Leven en werk van Margaretha van Godewijck (1627-1677), een veelzijdige dilettante (unpublished senior thesis, Katholieke Universiteit Leuven, 2006).

29 Ibid., 84-89.

30 Van Godewijck also had a younger sister, Cornelia van Godewijck, about whom we know virtually nothing. See Balen 1677 (as in n. 2), 1041. Her name is never mentioned in Van Godewijck's writings nor in the testament she composed after her mother's death in 1677; see Dordrecht, RAD, ms., archief 20: Notariële archieven van Dordrecht, no. 471, f. $176 \mathrm{r}-177 \mathrm{v}$. Cornelia van Godewijck had probably died previously.

31 These two Latin poems were posthumously published, the first by Balen 1677 (as in n. 2) and the second by Dirck van Bleyswijck, Vervolg van de beschryvinge der stadt Delft (Delft, 1681).

32 See n. 9. 


\section{The reception of Van Godewijck's Latin poetry}

As has become clear from the introduction, Van Godewijck's Latin poetry has only ever been engaged with superficially in the literature since her death. The existence of her two autographs was soon to be forgotten and even since their rediscovery in 1828 , her Dutch poems have been elevated almost at the expense of her Latin ones. Moreover, the few attempts that have been made to include the latter are often inaccurate. Schotel, for example, having had access only to ms. 1024, was unpleasantly surprised that "such a tasteful young woman had a preference for composing so-called versus Leonini", hinting at the less than purely classical and metrical, yet rhythmically written Latin poems he had seen (sc. poem IIa-VIa). ${ }^{33}$ Had he seen her other autograph, however, he might have nuanced his statement, as ms. 1025 contains solely prosodically classical poems, which actually form the majority of her Latin oeuvre. In fact, their classical prosody even seems to be the formal reason why Van Godewijck compiled this work in a distinct second manuscript.

Sometimes, Van Godewijck's poems have been wrongly attributed to her father. This, for instance, is the case with poem Va of the present edition, In furentes et fanaticos Anglos, bellum gerentes adversus Batavos ("Against the furious and frantic Englishmen, waging war against the Dutch"). The poem has a forceful, politically outspoken character, which elevates it from the typically more private confines of seventeenth-century women's writing. ${ }^{34}$ This could be a reason why Schotel attributed the work to her father, causing confusion that has had repercussions even in today's secondary literature. ${ }^{35}$ At other times, her Latin oeuvre has been too hastily described, resulting in unnecessary gaps and inaccuracies in Van Godewijck's scholarship. In Jane Stevenson's monumental Women Latin Poets from 2005, it is stated that Van Godewijck's autographs are

33 Schotel 1841 (as in n. 4), 51.

34 A. de Jeu, 't Spoor der dichteressen'. Netwerken en publicatiemogelijkheden van schrijvende vrouwen in de Republiek (1600-1750) (Hilversum, 2000), 196. For some other notable exceptions in the Low Countries, see L. Van Gemert, "Vijf vrouwen over oorlog en vrede", Historica 21.1 (1998), 7-9.

35 Schotel 1841 (as in n. 4), 135 n. 6. Schotel does, however, correctly mention Margareta van Godewijck as the author of this poem elsewhere; ibid., 102, n. 29. The wrong attribution to Pieter van Godewijck is adopted in W. Frijhoff, H. Nusteling, M. Spies (ed.), Geschiedenis van Dordrecht van 1571 tot 1813 (Hilversum, 1998), 347. 
"apparently lost" and that she "published at least one Latin poem". ${ }^{36}$ Her manuscripts, however, have been kept in the city archives of Dordrecht since circa 1900, and four of her published Latin poems have been identified since Schotel's influential 1841 biography. ${ }^{37}$

The most up-to-date, rigorous and sound analysis of Van Godewijck's poetry in general is arguably Annelies de Jeu's biography contained in 't Spoor der dichteressen from 2000, a study that focuses on women's network formation and opportunities for publication. ${ }^{38}$ Although specifically engaging with the Latin poems is not her primary concern, ${ }^{39}$ De Jeu successfully embeds Van Godewijck's literary oeuvre as a whole in a rich socio-historical context. Besides, she recognizes the remarkable function of the poet's Latinity that enabled her to show "these learned gentlemen [...] that she was fully capable of engaging with them". ${ }^{40}$ Nevertheless, De Jeu's overall narrative leans heavily on a close-reading of her Dutch poems, whereas the Latin ones are mostly considered for their titles, addressees, and publication (if the case) only. Moreover, the study overlooks some of the Latin and Dutch poems that were published, which to some extent undermines the conclusions De Jeu draws concerning Van Godewijck's opportunities for publication. ${ }^{41}$

36 Stevenson 2005 (as in n. 19), 353-354. Stevenson's appendix also includes references to Van Godewijck's Latin poems; ibid., 471-472. It is, however, incomplete and contains errors in both the titles of the poems and their first lines. Cf. the corrective review of D. Sacré, “Women Latin Poets. Some Notes”, Humanistica Lovaniensia 59 (2010), 377 390 , especially at 379 n. 1 .

37 Schotel 1841 (as in n. 4), 100 n. 28. In another article on Van Godewijck's emblems, however, Stevenson is aware of and engages with her autographs; Stevenson 2005 (as in n. 19). A fifth Latin poem hitherto not yet identified as published, can be found in Lambert van den Bosch, Sacrum melos, of kerck-geheymenis, dat is: schat der kennisse en dienst Godts. Oock des selfs goddelycke voorsienigheyt en rym-atlas, of sphaera mundi (Dordrecht, 1662), f. *7r. This is poem XIVb in the present edition.

38 De Jeu 2000 (as in n. 34). De Jeu's study is in a way a continuation of the monumental M.A. Schenkeveld-van der Dussen, K. Porteman, L. van Gemert, P. Couttenier (ed.), Met en zonder lauwerkrans. Schrijvende vrouwen uit de vroegmoderne tijd 1550-1850, van Anna Bijns tot Elise van Calcar (Amsterdam, 1997).

39 De Jeu only explicitly mentions her exclusion of primary texts other than in Dutch at the end of the work; De Jeu 2000 (as in n. 34), 280. In fact, however, she superficially mentions some of Van Godewijck's Latin poems in her discussion.

40 Ibid., 41.

41 De Jeu does not, for example, mention the two Dutch poems mentioned above in n. 11, and only provides two references to books that include a Latin poem by Van Godewijck, while there are at least five (see the notes to poems IVb, XIIb, XIVb, XXIb, and XXIIb of the present edition). 
Besides the clear factual errors made in discussing the Latin poems, the few opinions of their literary merits vary like day and night; many critics have trusted and repeated the verdict of Collot d'Escury, who, unlike Schotel, had had the opportunity to browse through ms. 1025 soon after its rediscovery in the nineteenth century. Unfortunately, he only briefly referred to Van Godewijck's Latin poems in his opus magnum Hollands roem in kunsten en wetenschappen. According to him, the poems were "not without merit and quite fluent", although he also added that "here and there she offends the quantity [sc. the metrical scheme]" 42 The latter part of this statement has, interestingly, often been omitted by those who quote him. ${ }^{43}$ Other critics have remained reticent, not addressing the quality issue at all. ${ }^{44}$ Some have deemed the poems "beautiful", others again have said they were "of poor quality", or have even gone so far as to say that they are not worth it to be rescued from oblivion. ${ }^{45}$ Strikingly, however, none of these findings are supported by any examples or further argumentation; indeed, Van Godewijck's Latin oeuvre often seems to merit but a mention, to be barely read, and virtually never discussed in any literary or critical context.

\section{Van Godewijck's Latin poetry}

Composing Latin metrical verse has been a celebrated, yet notoriously challenging activity since the decline of the language as a mother tongue and the general loss of any sensitivity to Latin's syllabic quantity in late antiquity. ${ }^{46}$ Presupposed in verse composition are the faculties of reading, writing, and widely comprehending Latin, all of which would be feasible only after many years of specialized education and training. ${ }^{47}$ Consequently, this practice constituted one of the culminating points of Latin

42 Collot d'Escury 1830 (as in n. 6), 162.

43 Schotel 1841 (as in n. 4), 51; BWN, vol. 7, 232.

44 De Jeu 2000 (as in n. 34).

45 Respectively P. van Beek, The First Female University Student (Utrecht, 2010), 127; Stevenson 2005 (as in n. 19), 354; Thijssen-Schoute 1952 (as in n. 20), 233.

46 Stevenson 2005 (as in n. 19), 20.

47 Ibid. 
education in the early modern period. ${ }^{48}$ For the Low Countries, the youthful poems, for instance, of Constantijn Huygens and Hugo Grotius are an illustrious case in point, although representing only the preeminent, successful peak of a vast body of student Latin verse endeavors. ${ }^{49}$

Since verse writing requires so much training, it is not surprising that the earliest Latin poems we encounter in Van Godewijck's oeuvre (present in ms. 1024) are either very short (poem Ia) or not metrical in the classical sense (IIa-VIa). The latter group were described by Van Godewijck herself as "versus rhythmici" and recall both in prosody and subject matter the lighthearted genre that is famously represented by the Carmina Burana..$^{50}$ The following lines, drawn from the poem In creationem mundi ("On the creation of the world"), are a perfect case in point. They display the characteristic, obvious elements of love, drinking and (ir)religion:

$$
\begin{aligned}
& \text { Homo tantum non creatur, } \\
& \text { quin et pane tunc cibatur; } \\
& \text { vinum facit hominem } \\
& \text { laetum et amabilem. }{ }^{51}
\end{aligned}
$$

Some other early rhythmic poems, however, are very similar in form to this, but remarkably different in nature, as they are composed for specific addressees. One of them, for example, is a poem dedicated to Johan van Beverwijck (poem VIa), an established physician in Dordrecht and author of the famous work Van de wtnementheyt des vrouwelicken geslachts

48 P.N.M. Bot, Humanisme \& onderwijs in Nederland (Utrecht, 1955), 169. See also the telling anecdote in K. Jensen, "The Humanist Reform of Latin and Latin Teaching", in J. Kraye (ed.), The Cambridge Companion to Renaissance Humanism (Cambridge, 1996), 63-81, at 74: "In 1526 the German humanist and religious reformer Philipp Melanchthon wrote that anyone unable to write poetry was not entitled to hold an opinion in learned matters, nor indeed could such a person be said to be a competent writer of prose".

49 See T. Ter Meer (ed.), Constantijn Huygens, Latijnse gedichten 1607-1620 (Den Haag, 2004); E.H. Bodkin, "The Minor Poetry of Hugo Grotius", Transactions of the Grotius Society 13 (1927), 95-128.

50 Poem IIa, 6, 8; VIa, 43.

51 IIa, 30-34. "Man is not only created, but also provided with food; it is wine that makes him merry and lovable." 
("Of the excellence of the female gender"). ${ }^{52}$ Occasional poems like this often provide us with an opportunity to consider the (relative) chronology of and within a corpus. In fact, for Van Godewijck's poem to Van Beverwijck, the terminus ante quem is 1647 , when she was about twenty years old, which makes it her earliest datable Latin poem. ${ }^{53}$

Whereas the Latin work in ms. 1024 is formally characterized by a lack of classical meter, ms. 1025 contains twenty-one elegiac poems and one in hexameters (IVb). Although most poems are undated, they are likely to have been written between roughly 1656 and 1663, with two clear exceptions from around a decade later (XXIb, XXIIb). ${ }^{54}$ Van Godewijck's metrical poems date therefore from a notably later period than her Latin work in ms. 1024. Unlike many of her Dutch poems, such as her series of emblem poems in ms. 1024, most of these texts are dedicated to a specific audience. They are focused on prominent figures in Dordrecht, including the burgomaster Adriaan van Bleyenburg (IXb), the renowned Amsterdam professor Arnold Senguerd and his son Wolferdus $(\mathrm{Xb}$, XVIb, XVIIb), the writer and poet Lambert van den Bosch (IVb, XIIb, $\mathrm{XIVb}$ ), and the local historian Matthijs Jansz Balen (XXIb).

Besides those poems dedicated to such individual men, several are addressed to larger groups of people, such as In cohortem septimam Plateae novae ("On the seventh cohort of the Nieuwstraat"; VIIb), while three are written to honor the students at the Latin school that Van Godewijck's father worked for (VIb, VIIIb, XVIIIb). In this category of poems, we may also include her poem Encomium Dordrechti (Ib), which, just like the earlier rhythmic poem Ad cives Dordracenos (IVa), constitutes an elaborate praise of the city of Dordrecht. This introductory poem of ms. 1025 is by far the longest in Van Godewijck's Latin oeuvre, which may prompt the conjecture as to whether it contains any extra profound, poetical or programmatic meaning. This may, indeed, be the case, as we

52 Johan van Beverwijck, Van de wtnementheyt des vrouwelicken geslachts [...] (Dordrecht, 1639). Some have claimed that Van Beverwijck mentioned Van Godewijck in his second edition from 1643; C.N. Moore, "Not by Nature but by Custom. Johan van Beverwijck's Van de wtnementheyt des vrouwelicken Geslachts", The Sixteenth Century Journal 25.3 (1994), 633-651, at 640; K. Porteman, M.B. Smits-Veldt, Een nieuw vaderland voor de muzen. Geschiedenis van de Nederlandse literatuur, 1560-1700, vol. 2 (Amsterdam, 2016 ${ }^{4}$ ), 431; Stevenson 2005 (as in n. 20), 163 n. 17. I have, however, not been able to find her name in this work.

53 This is the year in which Johan van Beverwijck died.

54 The terminus post quem for IXb is 1656; poem XVIb is dated May 1663. 
contemplate how and why Van Godewijck begins with the following lines:

Splendida quid iactat sua fortia moenia Roma, Tarpeius surgens tollit ad astra labor? ${ }^{55}$

Erigit ipsa suas ingens Florentia turres, luceat aethereo lumine celsa Pharos.

Nobilis illustris Venetum respublica Marci ostendit populos Hesperiaeque decus.

Nunc ut Dordrechti flammantia lumina fulgent, urbs his carminibus iam celebranda meis. ${ }^{56}$

These introductory lines merit some more attention. Praising a city in verse (so-called laudes urbium) is as old as literature itself, but it became especially popular in the humanistic literature of the Renaissance. ${ }^{57}$ Van Godewijck opens her work with a topos frequently deployed in this established encomiastic genre, a priamel. ${ }^{58}$ This means that the initial lines function as "a focusing or selecting device in which one or more terms serve as a foil for the point of particular interest". ${ }^{59}$ In this case, of

55 "Tarpeius surgens [...] labor" ("sheer Tarpeian toil") indicates the immense endeavor undertaken in order to build the Capitoline Hill, the heart of ancient Rome's political and religious life. The Tarpeian Rock is situated on the southern summit of the Capitoline Hill, but refers to the whole area (a pars pro toto).

$56 \mathrm{Ib}, 2-9$. "Why does splendid Rome boast of its strong walls? Why does sheer Tarpeian toil elevate it [sc. Rome] to the stars? Great Florence raises its towers, let lofty Pharus shine with heavenly light. The noble Republic of Saint Mark's displays the illustrious peoples of the Veneti and the glory of Italy. But where the shining lights of Dordrecht now glitter, that city is to be praised by these poems/verses of mine."

57 One could, for example, think about the praise of Uruk at the beginning and end of the Epic of Gilgamesh, or Lucr. DRN 6.1-6; Cat. Carm. 31; Verg. Aen. 1.419-439; Stat. Silv. 3.5.78-104. See F.P.T. Slits, Het Latijnse stededicht. Oorsprong en ontwikkeling tot in de zeventiende eeuw (unpublished doctoral thesis, Katholieke Universiteit Nijmegen, 1990), 215-301; C.W. de Kruyter, Constantijn Huygens, Stede-stemmen en dorpen (Zutphen, 1981), 3-20.

58 For the influence of literary and rhetorical traditions on the genre of occasional poetry, see A. Smeesters, Aux rives de la lumière. La poésie de la naissance chez les auteurs néo-latins des anciens Pays-Bas entre la fin du XVe siècle et le milieu du xviie siècle (Leuven, 2011), 2-13; and M.A. Schenkeveld-van der Dussen, "Poëzie als gebruiksartikel. Gelegenheidsgedichten in de zeventiende eeuw", in M. Spies (ed.), Historische letterkunde. Facetten van vakbeoefening (Groningen, 1984), 75-92, at 82. Note that Van Godewijck took her inspiration from a poem by Caspar Barlaeus (see apparatus fontium, ad loc.).

59 E.L. Bundy, Studia Pindarica (Berkeley, 1986²), 5. 
course, it is the unprecedented magnificence of Dordrecht, or rather its "lumina" ("lights"), a word with a double meaning that, like the English expression "shining lights", could signify both inanimate things and persons. ${ }^{60}$ Together with the next line, this one obviously announces the theme of Van Godewijck's first poem: a celebration of Dordrecht, her home city. At the same time, however, they - and with them the whole first poem in general - function programmatically for the ensuing poems in her manuscript (sc. ms 1025), as the majority deal with commemorating Dordrecht's prominent events, institutions, and intellectuals. ${ }^{61}$

The brief discussion provided so far shows that a notable portion of Van Godewijck's Latin poetry was not just written for private delight - as l'art pour l'art. From the total of 28 Latin poems, only six cannot be directly related to a specific occasion or prominent event. ${ }^{62}$ An important function of her work, therefore, is social, utilitarian and performative (Gelegenheitsdichtung). ${ }^{63}$ While this kind of poetry has been widely spurned by the influence of nineteenth-century literary aesthetics - a Romantic view only approves of "unmediated" emotional expressions of the highest degree of originality - it is important to recognize that this conception of what would be good literature cannot be applied to the early modern period. Amongst male and female authors alike, writing poetry for a birthday, wedding, funeral, or book publication was a muchloved activity, which formed an integral part of their literary lives. ${ }^{64}$ Indeed, a considerable amount of women's Latin writing that has been preserved is directly grounded in social and historical reality. ${ }^{65}$ These poems were usually not written for the sake of originality, but to maintain social ties with family, friends, or patrons, and showcase the poet's dexterity to employ rhetoric and the classical canon to luster a specific occa-

60 Cf. Cic. Cat. 3.10.24: "clarissimis viris interfectis lumina civitatis exstincta sunt".

61 Note that Van Godewijck wrote "his carminibus" ("with these poems"; Ib, 9) in the plural, which might also be an indication for the programmatic functioning of $\mathrm{Ib}$.

62 See poem Ia, IIIa, IVa, Ib, XIXb, XXb.

63 Schenkeveld-van der Dussen 1984 (as in n. 58), 75-92; I.A.R. de Smet, "Poetic Genres. Occasional Poetry. Theory", in P. Ford, J. Bloemendal, C. Fantazzi (ed.), Brill 's Encyclopaedia of the Neo-Latin World, vol. 2 (Leiden - Boston, 2014), 1144-1146.

64 Schenkeveld-van der Dussen 1984 (as in n. 58); Van Elk 2017 (as in n. 14), 89-96, 128-135.

65 J. Stevenson, "Female Authority and Authorization Strategies in Early Modern Europe", in D. Clarke, E. Clarke (ed.), 'This Double Voice'. Gendered Writing in Early Modern England (Basingstoke - London - New York, 2000), 16-40, at 22-23. The same holds for women writing in Dutch; see De Jeu 2000 (as in n. 34). 
sion. ${ }^{66}$ This is, of course, not to say that occasional poems are ipso facto void of any literary quality. ${ }^{67}$

The only downside of this occasional genre is the short lifespan and dispersed nature of these works. Many poems only circulated in manuscript or were printed as broadsides in relatively small quantities. As their content would often quickly lose significance after the occasion they were composed for, chances of survival would naturally decrease. ${ }^{68}$ Moreover, many occasional poems that were printed were incorporated in books of other (male) authors and therefore remain difficult to find ${ }^{69}$ The bias and obscurity of the sources make it hard to study the extent to which women's occasional writing in particular remained in manuscript rather than print. ${ }^{70}$ Like Van Godewijck, however, some authors luckily kept an album to collect and preserve their poetic contributions for the future.

In order to picture how Van Godewijck's work was valued by the contemporary audience that she tried to reach, it is important not only to take into account the occasional topics and dedicatees of her poems, but also to address the issue of her mastery of Latin verse composition. As the previous section on the reception of her poetry has made clear, a critical analysis of the quality of her work, reposing on examples, has never appeared and is still needed. This we now propose to remedy.

\subsection{Latinity and borrowings from other Neo-Latin authors}

To the eyes of a trained Latinist, the verses by Van Godewijck sometimes exhibit unusual (or, indeed, incorrect) syntax and prosody. Although the elegiac couplets do not always meet the high standards of the Golden Age poets, the majority are prosodically correct. Nevertheless, there are minor errors, such as "forum" (Ib, 43), "vivat" (Vb, 13), and "lyram" (VIIIb, 13). Most forms of Batavus and Bat(t)avia display unusual prosody as well (Ib, 32, 45, 52; Vb, 2, 14; XIIb, 2), but similar poetic license is more

66 Van Elk 2017 (as in n. 14); P. Gwynne, B. Schirg (ed.), The Economics of Poetry. The Efficient Production of Neo-Latin Verse, 1400-1720 (Oxford - Bern - Berlin Bruxelles - New York - Wien, 2018).

67 Cf. S. De Beer, "Poetic Genres. Occasional Poetry. Practice", in P. Ford, J. Bloemendal, C. Fantazzi (ed.), Brill 's Encyclopaedia of the Neo-Latin World, vol. 2 (Leiden - Boston, 2014), 1142-1143.

68 Schenkeveld-van der Dussen 1984 (as in n. 58), 76.

69 De Jeu 2000 (as in n. 34), 175-186.

70 Ibid., 281. 
widely shared amongst Dutch Neo-Latin authors. ${ }^{71}$ Only rarely do more problematic lines occur, as in XVIIb, 10, or XVIb, 15. The manuscripts, however, also contain instances where Van Godewijck corrected herself metri causa, for example her substitution of "mělius" for "plēnius" in $\mathrm{IXb}, 17$. In her rhythmic poems (sc. IIa-VIa), we occasionally find syllabic miscounts, as in Va, 4 and VIa, 23.

If we look at the syntax, mutatis mutandis the same holds. In general, the phrases are grammatically correct, yet oddities are clearly present and, admittedly, occasionally more serious errors, too. The use, for instance, of the present tense "turbantur" in Ib, 53 is curious, as is the beneficiary dative "vobis" in VIIIb, 18. A small inconsistency, for example, occurs in $\mathrm{Ib}, 24$, where the phrase in apposition is not in the right case, or again in $\mathrm{Ib}, 65$, where an indicative verb is used instead of the subjunctive. Another example of mediocre mastery is the word "splendidiore" (VIIb, 8), which, although metrically sound, should clearly be understood as "splendidius". Most serious are instances like "procul" (Xb, 14), which was likely intended as an adjective, and "ostendit" and "ostendens" (VIIb, 5, 14), which should be understood reflexively.

Besides the prosody and syntax, Van Godewijck's word choice, although predominantly classical, displays at times some odd characteristics. What should be mentioned here is her usage of specific conjunctions. A favorite is the clitic -que, especially when performing an explanatory function alongside the word delicium (see $\mathrm{Ib}, 24,38 ; \mathrm{Vb}, 16$ ), but also when it is simply serving as a clear metrical filler (e.g. Vb, 16: "civiumque"). Frequently notable is the deviant usage of sed (e.g. VIb, 12; $\mathrm{XIVb}, 3 ; \mathrm{XVb}, 17)$ and at (XVIIIb, v. 19), virtually meaning 'and', or sometimes being used without almost any significance.

As well as the word choice, the frequent recurrence of some phrases is also of note. This likely indicates that Van Godewijck compiled a socalled commonplace book with citations and passages she could readily incorporate into her own work. Indeed, this was a common practice for those learning to write Latin verse in the early modern period. ${ }^{72}$ Typical

71 In the oeuvre of Caspar Barlaeus, we find, for example: "Sufficiat gremio sponsa Bătāva suo; Et fulgens Bătăvae Nobilitatis honos; Haec est Battăviam vatis scribentis imago" (macrons and breves are added for clarity); see Barlaeus 1646 (as in n. 73), vol. 2, $75,223,415$. Because this prosodic licence is common, I have chosen not to repeatedly mark every single instance in the edition below.

72 S. Knight, "How the Young Man Should Study Latin Poetry. Neo-Latin Literature and Early Modern Education", in V. Moul (ed.), A Guide to Neo-Latin Literature (Cambridge, 2017), 52-65, at 58; Jensen 1996 (as in n. 48), 77. 
phrases that occur several times are "celebris tutela lycei" (IIb, 25; Xb, 19); "sic sonuere tubae" and "ingentes conticuere tubae" (Ib, 34; VIIb, 8 and IXb, 12; XVIIb, 6); "natalis [retulit]/[apparuit] festa colenda tui" (XVb, 4; XVIIb, 10); "carminibus iam [celebranda]/[celebrabo] meis" (Ib, 8; VIIIb, 18; Xb, 16) and "sum levior vates" (IXb, 11; XVIIb, 5).

Some of these phrases, however, and many other (parts of) lines that we encounter in Van Godewijck's Latin poems, can hardly be called 'Godevician'. A careful, critical study of Van Godewijck's Latin oeuvre reveals that, although never overtly quoted as such, lines and phrases drawn from near-contemporary printed books of Latin poetry find their way into her poetry. As the apparatus fontium of the present edition shows, the Poemata (1645-1646) of the renowned Dutch polymath Caspar Barlaeus was a particularly important resource for inspiration for her. A copy of the first volume with her signature in it still exists in the public library of Rotterdam. ${ }^{73}$ In the most extreme case, over ninety percent of the verses within a single poem derive from this work (poem XVIb). Many of Van Godewijck's poems, therefore, seem composed in an almost cento-like manner, which, however, I doubt she intended her audience to recognize.

A good example of Van Godewijck's deployment of Barlaeus' Poemata is her Encomium Dordrechti (Ib), which we have already briefly encountered. In composing this work, she picked lines from many different poems in his book. Typically, there is a faint pattern discernable in her borrowing. She often imitates several lines that in the original text are not

73 Caspar Barlaeus, Poemata, 2 vol. (Amsterdam, 1645-16464 [USTC 112813/USTC 1007637]). Van Godewijck's copy of the first volume of this $4^{\text {th }}$ edition was discovered already in 1834 by P.S. Schull, who wrote a short note including a photocopy of her insignia written at the front of the book; P.S. Schull, "Fac Simile van Margaretha Godewijck", in P.S. Schull, A. van der Hoop (ed.), Bijdragen tot boeken- en menschenkennis, vol. 3 (Dordrecht, 1834), 240-241. Currently, this copy is part of the collection of the public library of Rotterdam (kastplaats 1374 E 25, no. 915846). Together with her signature on the title page, Van Godewijck also wrote "1647", the year when the book came into her possession. It therefore seems probable that she also used the fourth edition of the second volume that came out in 1646, and not the fifth edition that appeared in 1655, a copy of which is also at the same library in Rotterdam. There is no evidence that Van Godewijck had contact with Barlaeus, although Schotel writes that there was a correspondence between the two of them; Schotel 1841 (as in n. 4), 84. This seems a dubious claim. Stevenson also assumes contact, based on a handwritten elegiac couplet written in Van Godewijck's copy of Barlaeus' Poemata; Stevenson 2005 (as in n. 19), 164165. The name "Godevicia" is indeed written underneath it, but the handwriting does not seem to be Van Godewijck's. It is mere guesswork to claim contact with Barlaeus on the basis of these two lines. 
directly consecutive, yet belong to the same poem. She then hops to another poem, sometimes connecting her borrowings with (presumably) her own lines. When choosing the poems from which to borrow, she selected many that either must have been familiar to her, or that had similar subject matter to her own poems. It is, for example, telling that she consulted Barlaeus' praise of Dordrecht for construing hers. ${ }^{74}$ Other poems likely caught her attention because they were addressed to famous Dordrecht individuals to whom she herself wrote laudatory verses. ${ }^{75} \mathrm{In}$ fact, such a desultory approach in reading collections of poetry was often practiced in the early modern period. ${ }^{76}$

Although the influence of Barlaeus' work is paramount, there are traces of many other authors discernable in Van Godewijck's poems. The authors she consulted include the Dutch savante Anna Maria van Schurman (1607-1678), Amsterdam poet Cornelius Giselbertius Plemp (15741638), French scholar Claudius Salmasius (1588-1653), Amsterdam polymath Daniel Heinsius (1580-1655) and his distant relative Iacobus Zevecotius (1590-1642), the German poet and professor Ioannes Stigelius (1515-1562) and his fellow countryman Georgius Fabricius (1516-1571), Walloon minister and headmaster Iacobus Crucius from Delft (15791655), French professor of rhetoric Iohannes Textor Ravisius (ca. 14801542), historian and professor of law Nicolaus Burgundius (1586-1649), and her father Pieter van Godewijck (see also the list provided at the end of section 6). ${ }^{77}$ For all the poems that contain intertextual features, however, it is clear that she made an effort to choose and restructure the lines that she deemed most apt, often changing them from the original, or

74 Barlaeus 1646 (as in n. 73), vol. 2, 402. See also the critical apparatus of Ib.

75 She consulted, for instance, Barlaeus' poems to the family members of the Van Beveren; see ibid., 218-221. Van Godewijck herself addressed two Dutch poems to Abraham van Beveren and one to Jacob van Beveren; see ms. 1024, p. 39-40, 56-57, 58-59.

76 Cf. J. Blaak, Literacy in Everyday Life. Reading and Writing in Early Modern Dutch Diaries (Leiden, 2009), 99-105.

77 On Crucius, Heinsius, Salmasius, Van Schurman, and Zevecotius, see $B W N$, vol. 3 , 892; vol. 8, 419-439; vol. 17, 33-53, 547-554; vol. 21, 45-47. On Plempius, see Toon van Houdt, "Cornelius Giselbertus Plemp", in J. Bloemendal, Ch. Heesakkers (ed.), Biobibliografie van Nederlandse Humanisten (online publication, 2009) (url: https://www.dwc.knaw.nl/biografie/humbio/). On Fabricius and Stigelius, see W. Kühlmann (ed.), Killy Literaturlexikon. Autoren und Werke des deutschsprachigen Kulturraums (Berlin - New York, 2008-2012), vol. 3, 354; vol. 11, 273-274. On Ravisius, see F. Hoefer (ed.), Nouvelle biographie générale, depuis les temps les plus reculés jusqu'à nos jours, avec les renseignements bibliographiques et l'indication des sources à consulter, vol. 41 (Paris, 1852-1866), 728. On Burgundius, see Allgemeine Deutsche Biographie, vol. 3 (Leipzig, 1876), 619. 
borrowing only the meaning, but not the words themselves (so-called imitatio rerum versus imitatio verborum) ${ }^{78}$ Only a minority of poems seem to lack any clear intertextual features at all, but this observation, of course, might well be countered in the future.

If, in conclusion, one considers Van Godewijck's sometimes undistinguished mastery of Latin together with her indebtedness to the work of others, one might conclude that the quality of her poems is rather poor. One could, for example, point out that she never attended Latin school, being a girl, or that her father and instructor, Pieter van Godewijck, might have realized the limited applicability of a thorough Latin education for his daughter. Yet this view would, I think, be inadequate. Similar to Van Godewijck, some of the most refined Neo-Latin poets from the Republic enjoyed their Latin education not at Latin schools, but in private. Moreover, her mastery of Latin has to be evaluated within the context of the degree of competence that students usually achieved. For the majority, this must have remained "at a depressingly mediocre level" at best, to put it strongly, and especially with regard to verse composition. ${ }^{79}$ In addition, the frequent use and incorporation of famous authors was a highly common practice amongst students. When held up against this standard, therefore, Van Godewijck's Latin poetry, poor as its quality may seem, should be considered a normal student accomplishment.

\section{History of the manuscripts}

From an early age onwards, Van Godewijck started to collect her own work, which she continued to do till she died. The earliest poem (in Dutch) in her collection is dated 1641 , when she was only fourteen years old, and can be found in ms. 1024. ${ }^{80}$ Most poems contained in ms. 1025 can, as has been said earlier, be dated later - two of them even up to 1677, the year she died (sc. XXIb and XXIIb). The earliest mention of the

78 This practice of imitatio through systematic appropriation was far from uncommon; cf. G.W. Pigman, "Neo-Latin Imitation of the Latin Classics", in P. Godmann, O. Murray (ed.), Latin Poetry and the Classical Tradition. Essays in Medieval and Renaissance Literature (Oxford, 1990), 199-210, at 204, who discusses the theory of Marco Girolamo Vida's De arte poetica (Paris, 1527).

79 Waquet 2001 (as in n. 16), 132. Cf. T. Keeline, S.M. McManus, "Benjamin Larnell. The Last Latin Poet at Harvard Indian College", Harvard Studies in Classical Philology 108 (2015), 621-642, at 636-637, where an occasional poem by Benjamin Gibson is discussed.

80 Ms. 1024, p. 5. 
two manuscripts after Van Godewijck's death was made the same year, by her friend Matthijs Balen in the appendices of his Beschryvinge der stad Dordrecht:

But because such misfortune has struck our city that that pearl [sc. Margareta van Godewijck] has passed away, I found myself obliged, in order to fulfill my indebtedness to her honor and memory, to add [...] what has come to hand and into my sight after her death: her noble Latin, Dutch, and French emblems, illustrated with various symbols [Dutch: Zinne-Beelden], artfully drawn by her own hand and colored with paint, as well as her Latin poems, varying in content, and several Latin letters written by her, primarily to Mr. Arnoldus Senguerdius, the late professor of philosophy in Amsterdam, including his letters of reply; in three unpublished books, separately bound. We have also seen many of her loose and unbound writings on various different topics, now being in the possession [...] of captain Samuel van der Heyden, Iohansz. ${ }^{81}$

Interestingly, Balen mentions three manuscripts, one of them containing Latin letters to and from Arnoldus Senguerdius. ${ }^{82}$ Besides these, Van Godewijck wrote at least three Latin poems to him, which are included in ms. 1025 (Xb, XVIb and XVIIb) and indicative of their active correspondence. The separate manuscript with prose letters, however, has never been recovered. A reconstruction of the trajectory of Van Godewijck's two other manuscripts is only partially feasible and relies heavily on surviving catalogues. Nevertheless, it is highly relevant, as in the absence of a printed edition, the owners of the manuscripts were instrumental in forming the reception of Van Godewijck's literary oeuvre.

81 See Balen 1677 (as in n. 2), f. Nnnnnnnn3-r: "Maar dewijle onze Stad het Ongeluk is te Beurd gevallen, dat die PAREL [...] is komen t'overlijden; Zoo vonden wy ons verplicht, tot voldoeninge van 't gene wy aan des zelfs Eere, en Geheugenisse schuldig zijn, By te Voegen; [...] 't geen ons verder, na haar dood, is ter hand gekomen, en Vertoond, hare E. Latijnze, Neder-Duytze, en Franze Emblemata, Vercierd met verscheyde ZinneBeelden, by haar zelfs Konstig Geteykend, en in Verwen Afgezet; noch hare Latijnze Gedichten, van verscheyde Stoffe, als mede verscheyde Latijnze Brieven, bij haar, voomamelijk aan d'Heer Arnoldus Senguerdius, Wylen Phil. Prof. tot Amsterdam, geschreven; Cum ejusdem Litteris responsoriis, in drie Ongedrukte Boeken, onderscheydentlijk Gebonden: Wijders hebben wy gezien vele van hare Losse en Ongebonden Schriften, bestaande in veelderhande Stoffe; Berustende, [...] onder Kapt. Samuel van der Heyden, Iohansz."

82 Cf. Schotel 1841 (as in n. 4), 84, 119 n. 111. 
As can be recovered from Balen's text, Van Godewijck's manuscripts probably came into the possession of Samuel van der Heyden, her nephew, although neither of her two wills specifically mentions them. ${ }^{83}$ Not until about a hundred years later, in 1781, does a catalogue clearly indicate that at least one of the three manuscripts eventually became part of the extensive book collection of Jacobs Willemsen (1698-1780), a preacher and professor of theology at the Athenaeum Illustre in Middelburg. ${ }^{84}$ Although his catalogue mentions Margaretae Godeviciae Poemata only once and without any specifications, I believe that ms. 1024 and 1025 are referred to together, and that this is therefore the latest conceivable terminus ante quem with regard to the separation of Van Godewijck's third manuscript from the three mentioned by Balen. This assumption is corroborated by the next catalogue we know of and that brings us back to the event described at the beginning of the present contribution: the auction of the book collection of Louis-Marie-Joseph Duriez from Lilles (1753-1825). After Willemsen's death, Duriez, a wealthy tax collector (receveur des finances), either directly or indirectly acquired Van Godewijck's two manuscripts containing her poems, as appears from the catalogue of books auctioned in Paris in 1828, three years after his death. ${ }^{85}$ From Paris, the two autographs were brought back to the Netherlands by Johannes Immerzeel.

The manuscripts were thus repatriated, and already before 1830 were acquired by the collector Jan Schouten (1786-1852). ${ }^{86}$ It was Schouten who showed one of Van Godewijck's manuscripts (sc. ms. 1024) to Schotel, who composed the first extensive biography of her in $1841 .^{87}$

83 Dordrecht, RAD, ms., archief 20: Notariële archieven van Dordrecht, no. 351, f. 49r-49v; Dordrecht, RAD, ms., archief 20: Notariële archieven van Dordrecht, no. 471, f. 176r-177v. These wills indicate that Van der Heyden is Van Godewijck's nephew. Cf. Schotel 1841 (as in n. 4), 87-88.

84 Bibliothecae Willemsenianae, pars sive catalogus librorum Latinorum, nitidissime compactorum bibliothecae instructissimae Viri Clarissimi \& plurimum Reverendi Jacobi Willemsen (Leiden, 1781), 173, no. 1999. It is known that some of Van Godewijck's embroidery was publicly auctioned in Dordrecht on 18 April 1678; see the advertisement in the Oprechte Haerlemsche Courant (Haarlem, 7 April 1678), 2.

85 Catalogue des livres imprimés et manuscrits, composant la bibliothèque de feu M.L.-M.-J. Duriez (de Lille) (Paris, 1827), 213, no. 2182.

86 Collot d'Escury 1830 (as in n. 6), 162.

87 This is mentioned by him in Schotel 1841 (as in n. 4), 88. Schotel also left a short note on an originally blank page at the end of ms. 1024, mentioning that one of Van Godewijck's Latin poems (sc. XIIb) could be found in Lambert van den Bosch, Britannias of herstelde majesteyt, helden-dicht (Dordrecht, 1661). 
Moreover, Schouten likely added the titles (Margaretae Godeviciae Poemata and Gedichten van Margareta Godewyk met XVIII door haar geschilderde zinne-beelden), short introductions, and indices to both manuscripts, including the beginning of the appendix to ms. $1024 .{ }^{88} \mathrm{In}$ November 1852, Schouten's collection was auctioned in Amsterdam, where Jacob van Dam van Noordeloos (1791-1872) became the new owner of the autographs. ${ }^{89}$ Around two decades later, they were separated from each other, when ms. 1024 was bought by Antonie Loffelt (18411906), who published an article on some of Van Godewijck's Dutch poems in an attempt to complement Schotel's earlier work. ${ }^{90}$ The other manuscript, however, was bought by "someone else", according to a note written by Loffelt on an originally blank page in ms. 1024. A stamp on the inside of the cover of ms. 1025 indicates that this must have been the antique bookseller Jan Emilius Engelberts from Rotterdam, but from here on we lose track. In 1907, Loffelt's widow donated ms. 1024 to the city archive of Dordrecht. The manuscript bought by Engelberts, however, was already listed in the catalogue of the Dordrecht archive in 1898, conjecturally obtained via the bequeathed collection of Pieter Beelaerts (1805-1892). ${ }^{91}$

\section{Margaretae Godeviciae poemata omnia quae extant Latina, tam metrica quam rhythmica}

\section{Editorial principles}

The poems in the critical edition below are arranged with respect to the order in which they occur in the manuscripts. The Roman numbers assigned to each individual poem are not original, but supplied for ease of

88 Cf. J. Alleblas, "De omzwervingen van Margaretha's dichtbundels", ([s.1.], 2014), 4 (unpublished manuscript). Stevenson, however, claims that "[t]he title [of ms. 1024] is Van Godewijck's own"; Stevenson 2005 (as in n. 20), 173.

89 Catalogus van eene kunstkeurige en wetenschappelijke verzameling van eenige Duizenden prentverbeeldingen, portretten, numenten, [...] Alles met uitgebreide kennis bijeenverzameld en nagelaten door wijlen den Wel-Edelen Heer Jan Schouten [...] (Amsterdam, 1852), 48, no. 88, 89. Van Dam van Noordeloos showed ms. 1024 to Johannes van Reyn (1829-?), who wrote a short treatise on Van Godewijck in his Nederlandsche vrouwen van vroeger en later tijd, geschetst in hare lotgevallen en verdiensten (Rotterdam, 1863); see ibid., 75-76, 80-81. His work is mainly based on Schotel 1841 (as in n. 4), but does not mention him.

90 See Loffelt 1876 (as in n. 6), 96.

91 J.C. Overvoorde, Catalogus van de bibliotheek der gemeente Dordrecht, afdeeling 1: Dordrecht en omstreken (Dordrecht, 1898), 270. See Alleblas (as in n. 88), 6. 
reference. These are followed by the letter 'a' or ' $b$ ', indicating that a particular poem stems from ms. $1024(=\mathrm{a})$ or ms. $1025(=\mathrm{b})$ respectively.

The original orthography and rather abundant punctuation found in the autographs have been completely modernized, as in toto preservation was considered to be an unnecessary complication for the modern-day reader. With regard to orthography, -j- (e.g. "negotijs", "jam") has been classicized to -i-, -e- ("secula", "prebuit") to -ae-, and -ch- ("charissimum") to -c-. Long - $f-$ has been normalized to short -s-, as have ligatures and ampersands to their full equivalent. Archaizing forms such as "heic" or "turreis" have been classicized, too. Capitals have only been maintained at the beginning of a sentence, in proper names, derived adjectives, unambiguous anthropomorphisms, book titles, and, following the original capitalization, in designations of the persons of the Trinity ("Deus", "Numen"). All accents ("rité", "hîc") have been removed.

The punctuation has been modernized on the basis of the original. Those few cases in which the adaptation or insertion of punctuation possibly changed the meaning of the text are recorded in the apparatus. It should be mentioned, however, that the insertion of question and exclamation marks, frequently left out by Van Godewijck, has often been done silently, since their required presence is supported by other interrogative or exclamatory linguistic markers.

I have endeavored to create a readable edition that can also be conveniently consulted by non-specialists. The complete revision of the punctuation and spelling hopefully contributes to the accessibility of the texts. I have adjoined brief summaries in English to every single poem, which also clarify the more obscure references or meanings. Remarks on prosody have all been assigned to the footnotes. Reconstructions of erasures from the autographs do not appear within the main text, but all deviations from the autographs are accounted for in the critical apparatus following each poem, in which I simply refer to the relevant autograph as cod[ex]. Unaccounted for is the systematic deletion of Van Godewijck's signature, usually spelled "Margareta Godewyk", which she wrote at the end of every single poem. It has been retained only in the case of more elaborate, i.e. non-standard closure, as in IIa, XIIIb, XVb and XXb.

With regard to the critical apparatus and Van Godewijck's autographs, two important final considerations need to be addressed. First, the autographic character of the two manuscripts should be considered as relative; it remains beyond doubt that they are written in Van Godewijck's hand, yet the embellished handwriting, as well as the frequent dittography, are clear indications that she copied her poems from loose pieces of paper, 
which resulted in the many scratchings found in the manuscripts. Consequently, I have not hesitated to emend the (supposed) errors that have crept into the manuscripts as an unwelcome result of Van Godewijck's copying (see, e.g., IVa, 16; XIb, 22; XIIIb, 1). All the poems, however, are based in primis on the authority of the manuscripts, with the sole exception of $\mathrm{IVb}$, for which I have used the printed version by Lambertus Sylvius (for more detail, see $a d$ loc.). ${ }^{92}$

The second consideration, on the other hand, functions as a crucial counterweight to the emendational urge advocated by the first. Looking at the general quality of Van Godewijck's poetry, one should, after all, seriously question whether even the supposed archetype would have been impeccable with respect to the grammar and prosody. ${ }^{93}$ Therefore, I have often resisted adopting possible emendations that seemed to serve the erudition of the modern-day philologist rather than the authenticity of her poems. ${ }^{94}$ I have, for instance, not altered "mei" in meae in IXb, 15, although it should modify the feminine word "mentis" within that same line. Neither have I changed "memorantes" to memorantia in XIIIb, 9, which Van Godewijck likely intended to agree with "carmina" in the next line. These errors - at all times identified in the apparatus - are unlikely to be the result of any lapse in transcription, but are part of, and therefore properly reflect, Van Godewijck's Latinity.

\section{Apparatus fontium and index abbreviationum}

The poems of Margareta van Godewijck feature many different intertexts that can be traced back to the books of (near) contemporary Neo-Latin authors (see also section 4.1). Therefore, a separate apparatus fontium has been adopted, situated between the end of every poem and the critical apparatus. All non-classical works are referred to by means of a capital-

92 It should be mentioned that a hand-written transcript of parts of ms. 1024, including some of Van Godewijck's Latin poems, was made by Gilles Schotel around 1841; Den Haag, Koninklijke Bibliotheek, ms. $128 \mathrm{~F} 10$. I have not been able to consult this transcript. As it carries no independent authority, however, it has no value for the present edition.

93 Because we have only a (possibly corrupted) copied text at our disposal, I am aware of the unavoidable potential circularity in this reasoning. The grammatical and prosodic errors that can be found in the manuscripts are, however, both in quantity and in quality, too frequent and/or consistent to be considered just transcribal flaws.

94 Cf. J. Culler, "Anti-Foundational Philology," in J. Ziolkowski (ed.), On Philology (University Park, 1990), 49-52, at 51: "Frequently [...] emendations from the past [...] seem to tell us more about the culture and assumptions of the philologists, the deficiencies in their understanding or ability to appreciate the otherness of a text, than they do about the original text itself."

Humanistica Lovaniensia 70.2 (2021), 229-303 
ized three-letter abbreviation, directly followed by the page number that displays the same phrase(s) as or (a) similar phrase(s) to the one(s) that the entry pertains to. For ease of reference, these phrases are quoted as well. The books referred to and the corresponding abbreviations are given below. Please note, however, that in many cases it cannot be ascertained if Van Godewijck used the exact same edition as quoted in this index.

ASO Anna Maria van Schurman, Opuscula Hebraea, Graeca, Latina, Gallica, Prosaica \& Metrica (Leiden, 1648 [USTC 1028616]).

CBP Caspar Barlaeus, Poemata, vol. 1 (Amsterdam, 1645 [USTC 112813]).

CBP2 Caspar Barlaeus, Poemata, vol. 2 (Amsterdam, 1646 [USTC 1007637]).

CPM Cornelius Giselbertus Plempius, Musius, sive rhythmi, cum poematiis (Amsterdam, 1618).

CSD Claudius Salmasius, Defensio regia pro Carolo I (Paris, 1650 [USTC 6008573]).

DHA Daniel Heinsius, Auriacus sive libertas sancia (Leiden, 1602 [USTC 1027616]).

DHP Daniel Heinsius, Poemata Latina et Graeca. Editio post plurimas postrema, longe auctior (Amsterdam, 1649 [USTC 1030580]).

GFP $^{2}$ Georgius Fabricius, Poematum sacrorum libri $X X V$, vol. 2 (Basel, 1567).

ICM Iacobus Crucius, Mercurius Batavus sive epistolarum libri V (Amsterdam, 1660).

IRD Iohannes Textor Ravisius, Dialogi aliquot [...], epigrammata [...], et epistolae non vulgaris editionis (Genève, 1600).

ISP Ioannes Stigelius, Poemata, vol. 1 (Jena, 1566).

ISP2 Ioannes Stigelius, Poemata, vol. 2 (Jena, 1566).

IZP Iacobus Zevecotius, Poematum editio nova (Leiden, 1625 [USTC 1028555]).

NBP Nicolaus Burgundius, Poemata (Antwerp, 1621).

PGO Pieter van Godewijck, Olyf-tack op den eeuwige-vrede [...] (Dordrecht, 1648).

PGT Pieter van Godewijck, Tranen uut-gestort van de maeght van dordrecht, over het droevigh af-stervan des Godsaligen vromen ende hoogh-geleerden D. Iohannis Westerburgh (Dordrecht, 1636). 
$I a^{95}$

In this poem, Van Godewijck expounds on her last name 'Godewijck,' which includes the Dutch words for 'God' and 'shelter.' Her father had already transformed this family name into the motto 'tot Gode [is ons] wijck' ('God is my shelter'), which he often placed at the end of his published works, sometimes as a pseudonym. He also used the Latin variants 'Deus mihi vicus,' and 'Deus nostrum asylum.' Here, Van Godewijck is evidently hinting at this motto and its significance: Christ will always be her safe ward; cf. poem XXb.

In symbolon meum, 'Deus nostrum asylum'

Seu morior seu vivo meum sit Christus asylum, mortis hic et vitae sacra sit ara meae.

tit. Deus nostrum asylum] cf. V.T. Ps. 17.3-5, 45.2, 90.2

$I I a^{96}$

Van Godewijck responds to a (lost) 'rhythmic' poem that her father had written to her. She first recounts her joy at receiving his poem (vv. 1-8). Unfortunately, however, she lacks the time to express her gratitude properly; she is always occupied with domestic duties (vv. 9-20). Nevertheless, she tries to work as hard at night as the Greek philosopher Cleanthes allegedly did (vv. 21-24). She loves studying and despises those who, instead, waste their time (vv. 25-32). Then she tells her father that she did not appreciate his praise of her. He, however, should be glad about the honor that he receives (vv. 33-36). In the penultimate passage, she praises God, bestower of wisdom, life, and grace - may he be favorable to him (vv. 37-44). Finally, she wishes him a happy life with her dear mother (sc. Sara Cornelisdr Pijpelaar) (vv. 45-48).

95 Ms. 1024, p. 200. Van Godewijck also wrote a similar poem on her last name in Dutch: Op de Naem Godewyck; see ibid., p. 198-199.

96 Ibid., p. 239-243. 
Responsio ad parentem meum carissimum, D. Petrum Godewyck, cum nuper ad me dedisset versus suos Latinos rhythmicos

Pater care, cum legissem

opus tuum rhythmicum,

et cum gaudio vidissem

carmen tuum musicum,

tum accepi suavitatem

ex hoc honorario,

etiam hilaritatem

ex isthoc donario.

O si mihi ad reddendum

nunc restaret aliquid!-

prompta sum ad largiendum;

tempus mihi deficit.

O si otium haberem

ad haec exercitia!-

sane, ego tum gauderem;

procul sit inertia.

Semper iam sum occupata

rebus oeconomicis,

et diebus implicata

in multis negotiis. ${ }^{97}$

97 It is a commonly deployed topos for early modern women writers to refer to their obligations in managing the household both as an apology for their (alleged) literary inactivity or incapacity, and as proof of their domestic virtue; cf. Schenkeveld-van der Dussen, Porteman et al. 1997 (as in n. 38), 8, 39-43; see for instance Johanna Othonia's letter to Camille de Morel in J. Stevenson, "Johanna Otho (Othonia) and Women's Latin Poetry in Reformed Europe", in L.J. Churchill, Ph.R. Brown, J.E. Jeffrey, Women Writing Latin. From Roman Antiquity to Early Modern Europe, vol. 3 (New York - London, 2002), 189-215, at 192 . 
Ego conor imitari

philosophi exemplum,

qui debebat operari,

nocte scripsit librum. ${ }^{98}$

Amo vere et libenter

ista alta studia;

doleo, qui indecenter

tractant hic inania.

Illi semper in hoc mundo

abutuntur tempore;

manent in impuro fundo

cum scelesto pecore.

Hoc non fuit mihi gratum

quod me tollis laudibus;

et tu putas te beatum

in tantis honoribus.

Dato Deo omnem laudem

qui dat sapientiam,

et qui docet inscientem,

habe illi gratiam.

Deus ille qui creavit

omnia ex nihilo,

et qui populum beavit,

sit tibi propitio.

22-24 philosophi ... librum] cf. Diog. L. 7.5

22 philosophi: Cleanthes add. in marg. cod. | $\mathbf{3 5}$ putas intellegas puta vel putes | $\mathbf{4 4}$ propitio adiectivum pro substantivo ponitur

98 In the margin of the manuscript, Van Godewijck refers to the Greek philosopher Cleanthes, who allegedly used to draw water in gardens by night to support himself (cf. Diog. L. 7.5). She slightly confuses the story, as she writes that he committed himself to philosophy during the night.

Humanistica Lovaniensia 70.2 (2021), 229-303 
Care pater, bene vale

cum mea matercula;

opto ut non vivas male cum tua carissima.

Margareta Godewyck.

Deus mihi vicus.

Seu morior seu vivo, Christus meum asylum.

III $a^{99}$

Van Godewijck celebrates God's creation of the world (in the vein of Psalm 103: 'Benedic anima mea Domino'), addressing him directly. He has created the earth and all life that flourishes on it; his glory is everywhere (vv. 1-12). She continues with a description of the earth: it is immovable, fixed in heaven (vv. 13-14), and contains rivers, meadows, mountains, oceans, trees, birds, crops, cattle, wine-loving men, and (again) birds (vv. 15-36). Van Godewijck ends her poem with praise addressed directly to God, who is content with his creation and whose work is not just a dream, but reality (vv. 37-44).

In creationem mundi

Sancta manu condidisti, Deus, mundum et dedisti nobis tuam gloriam, rerum tuam copiam.

Agnos, equos, aves, boves, et dedisti nobis oves, quoque multa pecora; laudate Dei decora.

4 rerum ... copiam] cf. carm. VIa, 21

7 quoque ... pecora intellegas multa quoque pecora

99 Ms. 1024, p. 244-247. 
O Iehova! Rex Deorum, laus et gloria honorum,

et maiestas eminet, globum terrae continet.

Fundata terra nobilis

a te et est immobilis;

fluunt quoque flumina,

rigant humi gramina.

Et montes in cacumine, sunt alti celsitudine;

hi sunt mari limites, ponunt aquis stipites.

Arbores florent floribus, Et cantant aves moribus aures mulcent cantibus in ramis comantibus.

Terrae redundant frugibus, seminibus et messibus.

Pecus foeno pascitur, gramen dulce nascitur.

Homo tantum non creatur, quin et pane tunc cibatur; vinum facit hominem laetum et amabilem.

Alites hic nidos struunt, et pupillos quoque alunt; cum iam sunt volatiles volant et sunt faciles. 
Laus sit Deo per secula, est qui formavit aethera;

illi placent quae creavit, opus suum et probavit.

Divina Deo gloria

sit illi, et victoria, qui creavit omnia, vere non sunt somnia.

$I V a^{100}$

In this poem, Van Godewijck addresses Dordrecht's most prominent citizens rather critically. ${ }^{101}$ Having greeted them (vv.1-4), she introduces the theme of the poem: peace. She hopes that God will always grant them peace and happiness; that is all she wishes for (vv. 5-12). They have lost their inclination to live peacefully, and should therefore strive to regain it (vv. 13-20); let them live harmoniously (vv. 21-24). As a supplement, Van Godewijck quotes two passages in prose on the virtue of peace, one a Ciceronian paraphrase by her father, the other a paraphrase from the Old Testament.

Ad cives Dordracenos

Vos, qui Dordrechti sedetis, primum locum obtinetis, scripsi vestro nomine, sit foelici omine.

Deus faxit ut pacati

semper sitis et amati;

vestri cives rideant, cuncta vobis placeant.

100 Ms. 1024, p. 248-250.

101 Another option is to read the phrase "qui [...] primum locum obtinetis" (vv. 1-2) as referring to Dordrecht's special status as the oldest city, allowing it to always be the first to vote in the States of Holland (cf. poem Ib, vv. 29-30). The poem could then also be addressed more generally to all citizens. Other passages, however, such as "vestri cives" (v. 7), and "estote pacis patres" (v. 20), also imply that Van Godewijck is addressing politically prominent men in particular. 
Utinam id possem clare vobis semper dedicare,

vobis amatoribus, et pacis tutoribus.

Pacem ante dilexistis, ah! iam eam perdidistis; propinate iterum

in laudem pacis vitrum.

\author{
$\mathrm{O}$ ! vos omnes $\uparrow$ consuevistis ${ }^{102}$ \\ lites $\dagger$, rixas posuistis, \\ et inter omnes fratres \\ estote pacis patres.
}

Sitis semper hic concordes, et abite qui discordes

amant in hoc seculo;

pax sit grata corculo.

$\mathbf{1 7}$ consuevistis fort. mutandum in desuevistis aut consevistis | $\mathbf{1 8}$ lites fort. intellegendum quasi litibus | 19 et fort. intellegendum ut, aut omnino mutandum in vocem at

102 Both line 17 and line 18 pose some difficulties, since they can either be understood as positive (i.e. the citizens being peaceful) or negative (the citizens still being belligerent); one could read "consuevistis" as an ellipsis for consuevistis bellare (vel sim.), or exactly the opposite: consuevistis pacem diligere. Van Godewijck's punctuation, however, may suggest that lites should still be understood as an object of this verb (although consuesco normally does not directly take the accusative case), which would support a pessimistic reading. Alternatively, one could also emend to desuevistis (which can take an accusative; cf. Apul. Flor. 15.25) or consevistis. Depending on a positive or negative reading of this first part, the simplex predicate "posuistis" could be interpreted as either deposuistis or concitavistis. Finally, "et" (v. 19) could be emended to, or understood as at in order to promote a pessimistic interpretation.

Humanistica Lovaniensia 70.2 (2021), 229-303 
Nomen pacis dulce est, et res ipsa salutaris, sed quae nihil habet insidiarum, nam pax ea, sub cuius nomine fraus litat, aut bellum, omnino repudianda est. Cicero.

Beati pedes qui annuntiant pacem.

subscr. Nomen ... repudianda est] cf. PGO, 1 (sane ad litteram sumptum ex hoc Petri Godevicii opere, qui suis verbis descripsit Cic. Phil. 2.113) | Beati ... pacem] cf. V.T. Is. 52.7

$\mathrm{Va}^{103}$

Van Godewijck is furious about England's growing and provocative dominance after the establishment of the Commonwealth in 1649, which had led to the First Anglo-Dutch War (1652-1654). She describes how the Englishmen fiercely try to destroy Holland by naval battle (vv. 1-8). Then she asks God to destroy the enemy and sink their ships (vv. 9-16). Let him be helpful as he once was to Deborah the prophetess who, with the help of Jael, slew Sisera, the adversary (vv. 17-22). Let God grant them the Dutch victory (vv. 23-24). Again, Van Godewijck adds two passages in prose, the first a description of the decapitation of Charles I, taken from Claudius Salmasius' Defensio regia pro Carolo I, the second a comment on heavenly revenge taken from Valerius Maximus.

In furentes et fanaticos Anglos, bellum gerentes adversus Batavos

Angli veniunt destruentes ${ }^{104}$ classibus in patriam;

illi iam sunt deprimentes nostram Hollandiam. ${ }^{105}$

Illi fundunt iam cruorem in mare Batavicum;

illi excitant furorem saevum et tyrannicum.

103 Ms. 1024, p. 251-253. Van Godewijck also wrote an invective poem on the war with England in French: Sur la détestable Guerre des Anglois; see ibid., p. 268-271.

104 Note that rhythmically the word "veniunt" should likely count as two syllables (- $i$ is syncopated).

105 A syllable is missing in the rhythm. 
Surge, Deus, in virtute, fuge tales bestias;

pugna (precor) pro salute, dele has molestias.

Perde, perde hos molossos, flige naves Anglicas;

pelle, pelle hosce pravos, merge has Britannicas.

Fac ut Marte iam vincamus thalassiarchum robora; tua fide iam pugnamus, iuva nos ut Debora.

Quae occidit inimicos, manu forti Siseram.

Oro, Deus, flige malos, da nobis victoriam.

Salmasius in Defensione Regia, pro Carolo I:

$E$ carcere rex educitur, in domum regiam adducitur, coram iudicibus selectis sistitur, causam dicere tanquam reus cogitur, non respondens condemnatur, securi percutitur. Sed quomodo? Eo modo quo nullus umquam rex supplicium capitis passus est. Ut latro, ut sicarius, ut parricida, ut proditor, ut tyrannus ante domum suam, id est regiam aulam, populo spectante, in infami pegmate positus, inter duos carnifices constitutus, et quidem larvatos. Eo usque Salmasius.

Heu dolor! Deus puniet istos fanaticos Anglos. Lento gradu ad vindictam sui divina procedit ira, tarditatemque supplicii gravitate compensat.

20-22 ut ... Siseram] cf. V.T. Iud. 4.1-24 | subscr. E carcere ... larvatos] cf. CSD, 4 (ad litteram) | Lento ... compensat] cf. Val. Max. Mem. 1.1. ext. 3 
$V I a^{106}$

In this poem, Van Godewijck praises her fellow citizen Johan van Beverwijck (1594-1647), a famous doctor of medicine and surgery and a colleague of her father, who later also became alderman (Dutch: schepen; Latin: scabinus). ${ }^{107}$ Instead of addressing him directly, she talks to the citizens of Dordrecht in general, ${ }^{108}$ first mentioning the topic: 'I am celebrating Van Beverwijck' (vv. 1-3). Then she offers his curriculum vitae: he was born in Dordrecht and excelled in his studies (vv 4-6); he also studied in Leiden and France, where he obtained his doctor's degree (in fact, this was in Padua) (vv. 7-15); he traveled to Lyon and also to Italy (vv. 16-18). He is a talented, generous, and honorable man (vv. 1930). He respected and was familiar with important figures like Cornelis Boy (1611-1655), Daniel Heinsius (1580-1655), and Claudius Salmasius (1588-1653) (vv. 31-36). Van Godewijck finishes rather abruptly: she has now written enough (vv. 37-42).

In laudem doctissimi viri clarissimique Iohannis Beverovicii, scabini et doctoris medicinae primarii apud Dordracenos

Quid iam scribo, si vis scire,

possum paucis expedire:

laudo Bevervicium;

in hac urbe erat natus,

et a multis veneratus

propter suum studium.

1-2 $\mathrm{Si}$... expedire] cf. CPM, 9: "Si vis, lector, quis sim scire, / possum paucis expedire"

6 veneratus: veneratum $a$. ras. cod.

106 Ms. 1024, p. 254-257.

107 Cf. G.D.J. Schotel, De illustere school (Utrecht, 1857), 79-80; De Jeu 2000 (as in n. 34$), 42$.

108 See "in hac urbe" (v. 4). The deictic pronoun makes clear that the audience is expected to (co-)identify with the city of Dordrecht. 
Ille Leidae habitavit, et memoriae mandavit scita naturalia;

Graeca lingua cum Latina,

et Leidensi disciplina

usus est et alia.

Post ad Gallos veniebat,

ibi doctor tum fiebat;

multis quoque placuit.

Tum Lugdunum est profectus, et Italiam provectus diligenter studuit.

Mox poetis laureatis

gratus erat ceu cognatis

rerum propter copiam;

doctus erat et humanus,

nummos pauperi dans in manus, ${ }^{109}$

sustulit inopiam.

Numquam fuit cuiquam gravis,

semper mitis, erat suavis;

multas amicitias

sibi soli comparavit,

numquam neminem vexavit,

abhorruit nequitias.

8-12 Et ... alia] cf. CPM, 10: "et memoriae mandavi / scita naturalia; / Graecam linguam cum Latina / ex Castrensi disciplina / sum nactus, et alia" | 19-21 Mox ... copiam] cf. CPM, 10: "mox poetis laureatis / gratus eram ceu cognatis, / rerum propter copiam" | 21 rerum ... copiam] cf. carm. IIIa, 4 | 23-24 nummos ... inopiam] cf. CPM, 10: "nummos mihi dans in manus / sustulit inopiam" | 25-30 numquam ... nequitias] cf. CPM, 11: "Numquam fui cuiquam gravis; / semper mitis, ac suavis / multas amicitias / unus mihi comparavi, / nec suas quemquam vexavi / dicax ob nequitias"

16 Lugdunum: Lions add. in marg. cod. | 20 ceu scripsi: seu cod.

109 Note that rhythmically the word "pauperi" should likely count as two syllables (-e- is syncopated).

Humanistica Lovaniensia 70.2 (2021), 229-303 
Boyum, Heinsium adspexit, et Salmasium dilexit, decora Batavia;

hosce saepe audiebat, ille etiam sciebat

quod essent magno nomine.

Satis rhythmicos cantavi, satis versus hos amavi, ego demum desino.

Iam non possum plura scribere, ${ }^{110}$

neque Hippocrenas bibere, tandem ego finio.

Finis.

Margareta Godevicia.

Christus mihi vicus, solus mihi amicus.

40 Iam ... scribere] cf. Cic. Att. 11.2.3

41 Hippocrenas: Musicas add. in marg. cod.

$I b^{111}$

This encomium of Dordrecht is markedly the longest Latin poem in Van Godewijck's oeuvre. She starts off by introducing the topic: praise of Dordrecht, the most eminent of all cities (vv. 1-8). She then recounts what is known as the St. Elizabeth's flood of 1421, which caused enormous damage to the city's hinterland (vv. 9-12). Parts of the land, however, were recovered (vv. 13-16). A description of the most prominent buildings of the city follows, mentioning amongst others the houses of Adriaan van Bleyenburg (1616-1682) and Abraham van Beveren (1604-1663) (vv. 17-28). The next section narrates some historical facts: being the oldest city, Dordrecht was always the first to vote in the States of Holland, and the first free assembly of the States of Holland was held here in

110 For "scribere" and "bibere" (see next line) the same holds as for "pauperi" in line 23 (see note above).

111 Ms. 1025, p. 1-5. Van Godewijck also wrote a long but different poem on Dordrecht in Dutch: Op Dordrecht, Myn geboortens Stadt; see ibid., 305-313. 
1572 (vv. 29-34). There follow a description of the city's important mercantile position (vv. 35-44), and an apostrophe addressing the Virgin of Dordrecht (vv. 45-46; cf. IIIb, 9), who successfully repelled Fernando Álvarez de Toledo, Duke of Alba (referred to as 'Albani rabiem'), while Rotterdam wept and suffered under the attack of Maximiliaan de HéninLiétard, Count of Bossu, in 1572 (vv. 47-52). As the final and most recent historical event, Van Godewijck describes the Synod of Dort (16181619), which safeguarded true Christian religion (vv. 53-60). These historical events, in turn, are transformed into a conclusive, real-time wish addressed to God: may peace, freedom and faith always be thriving for this city! (vv. 61-66).

\section{Encomium Dordrechti}

Splendida quid iactat sua fortia moenia Roma, Tarpeius surgens tollit ad astra labor?

Erigit ipsa suas ingens Florentia turres, luceat aethereo lumine celsa Pharos.

Nobilis illustris Venetum respublica Marci ostendit populos Hesperiaeque decus.

Nunc ut Dordrechti flammantia lumina fulgent, urbs his carminibus iam celebranda meis.

Merserat australes iam quondam fluctibus agros, totque ferox late sorpserat unda lares.

Deseruere domos Nymphae; trux undique Nereu, undique crudeles, incubuistis, aquae.

1-4 Splendida ... Pharos] cf. $\mathrm{CBP}^{2}, 414$ : "Splendida Romano surgant Capitolia luxu, / luceat aethereo vertice celsa Pharos. / Ammonii delubra Iovis, Triviaeque penates / Afer et Argolicus tollat in astra labor. / Erigat ipsa suas generosa Semiramis arces" | 8 carminibus ... meis] cf. $\mathrm{CBP}^{2}$, 174: "praedia carminibus nunc celebranda meis"; carm. VIIIb, 18; Xb, 16 | 9-12 Merserat ... aquae] cf. $\mathrm{CBP}^{2}, 219$ : "Merserat Australes funestis fluctibus agros / totque ferox late sorpserat unda lares. / Deseruere domos Satyri; trux undique Nereu, / undique crudeles incubuistis aquae" 
Postea migravit Triton cum Thetide circum, ${ }^{112}$

et madidos pepulit Vesta Dryasque deos.

Fecundis cinguntur agris tot cincta procellis

praedia, quaque fuit fluctus et arva virent.

Aedes si spectas, veteris vestigia saecli,

bellaces heroum aspice, Belga, manus. ${ }^{113}$

Tecta Blyenburgi late tollantur in altum, altius augustum tendit ad astra caput.

Ultro si pergas vastam te ferre per urbem, magnas spectabis marmoreasque domos.

Hinc Beveri magnas lustrabis consulis aedes, ${ }^{114}$ gloria conspicuae deliciumque domus.

Hinc etiam cernis magnos attollere fasces, ad morem Fabii, maxime consul, eas.

Templum si spectes, aulam, magnamque monetam: munera sunt Caroli barbariaeque metus.

Urbs prima ordinibus suffragia liquida donat, ${ }^{115}$ et pia, sed tutae, nomina pacis amat.

13-18 Postea ... manus] cf. CBP2, 232-233: "Mutasti, Neptune, domos, et Nerea circum / et madidos pepulit Vesta Dryasque deos. / Fecundis cinguntur agris tot cincta procellis / moenia; quaque fuit pontus, arena viret. / Quisquis saxa vides, veteris vestigia saecli, bellacesque patrum suspice, Belga, manus" | 20 altius ... caput] cf. $\mathrm{CBP}^{2}, 409$ : "altius augustum tollit ad astra caput" | $\mathbf{2 4}$ gloria ... domus] cf. Mart. Epigr. 7.50.2 | 29-30 Urbs ... amat] cf. $\mathrm{CBP}^{2}, 221$ : "iam patriae donat mediis suffragia bellis. / Iam pia, sed tutae, nomina pacis amat"; carm. XVb, 8

$\mathbf{2 4}$ gloria intellegas gloriam

112 Note that "postea", a cretic word, is likely intended as a dactyl. Alternatively, one could read the split variant post ea. It is questionable, however, whether this latter reading would in fact reflect Godevician authenticity or philological fetishism.

113 Note the non-standard elision over the point of the mid-caesura of the pentameter (cf. Cat. Carm. 73.6).

114 On Abraham van Beveren's magnificent house, see also Van Godewijck's Dutch poem $O p$ 't Ghe-Bouw vande Heer Abraham van Beveren, Heere van Barendrecht; ms. 1024 , p. 39-40.

115 The metrically incorrect word "liquida", intended as a dactyl, is in fact a tribrach. 
Auriacus dum fortia magnus ad arma rediret, Mavors invictus Battaviaeque decus,

hic primum ante urbem tunc colligere agmina coepit, primae hinc belli sic sonuere tubae. ${ }^{116}$

Frugifer Autumnus mediam transmigrat in urbem, attamen arboribus littora nostra carent.

Est nondum nobis pinguis vindemia Bacchi, nec molles uvae deliciumque Mosae.

Huc Rheni merces et vini munera mittunt, et Nemetes plenis mustea vina cadis.

Sed Tungri ferrum, commercia plurima donant vastaque Eburonum marmora caesa iugis.

Hic forum est magnum, Brittorum maxima merces, ${ }^{117}$ semper Brittanni quod coluere viri.

Quid plus cantarem, Batavorum maxima virgo?

Suspice: Fama etenim te super astra vehet.

Quondam tormenta Albani et rabiem repulisti

a Dordracenis sanguinolenta focis,

efferus in sociam cum se Bossuvius urbem funderet, et trepidis Rottera fleret aquis.

At nunc prima sedes inter, non victa, sorores, artificum nutrix Battaviaeque decus.

34 sic ... tubae] cf. $\mathrm{CBP}^{2}$, 65: "Ingentes conticuere tubae"; carm. VIIb, 8; IXb, 12; XVIIb, $6 \quad \mathbf{3 5}$ Frugifer ... urbem] cf. $\mathrm{CBP}^{2}$, 402: "Pomifer Autumnus mediam transmigrat in urbem" | 39-41 Huc ... donant] cf. $\mathrm{CBP}^{2}$, 402: "Huc Tungri merces, et ferri munera mittunt, / et Nemetes plenis mustea vina cadis" | $\mathbf{4 2}$ vastaque ... iugis] cf. $\mathrm{CBP}^{2}$, 402: "vastaque Eburonum marmora caesa iugis" | 47-50 Quondam ... aquis] cf. $\mathrm{CBP}^{2}$, 220: "Tu ducis Albani rabiem, tu tela repellis / a Dordracenis sanguinolenta focis. / Efferus in sociam cum se Bossusius [sic] urbem / funderet et trepidis Rottera fleret aquis" | 51 inter ... sorores] cf. $\mathrm{CBP}^{2}, 402$ : "Tunc Batavas inter vigui non victa sorores"

32 comma post vocem decus ego posui pro puncto $\mid \mathbf{4 1}$ sed ut vid. vera vocis vi caret 45 Batavorum scripsi: Battavorum cod. | interrogandi signum in fine versus posui pro commate $\mathbf{4 8}$ comma post vocem focis ego posui pro puncto

116 Note the hiatus in this line.

117 The word "forum" does not fit the hexameter. Van Godewijck was likely unaware that the first vowel is naturally short. 
Quondam turbantur magna caligine mentes, vix servabatur relligionis amor.

Sed rixis tremuere ardentia limina Phoebi, nec iustus iudex aut gravis ultor erat.

Prodibant Dordrechti omnes ex ordine patres, hic templum pacis sed pietatis erat.

Curia tunc strepitu, tunc aures lite vacabant, omnes florebant uberiore fide.

Florebit felix concordia semper in urbe, pectora sed numquam vindice fide carent.

O summum Numen, magnus Regnator Olympi, excipe quos querulo fudimus ore sonos.

Ut nobis aeterna manent caelestia dona, ${ }^{118}$ optima libertas, religionis amor.

\begin{abstract}
56 iudex ... erat] cf. $\mathrm{CBP}^{2}$, 72: "nec sceleri iudex aut gravis ultor erat" $\quad \mathbf{5 9}$ Curia ... vaca-bant] cf. $\mathrm{CBP}^{2}, 72$ : "Curia tunc strepitu, tunc aures lite vacabant" | 64 excipe ... sonos] cf. $\mathrm{CBP}^{2}, 34$ : "excipe, quos querulo fundimus ore sonos"

$\mathbf{5 3}$ turbantur intellegas turbabantur $\mid \mathbf{5 8}$ sed intellegas et $\mid \mathbf{6 5}$ manent intellegas maneant
\end{abstract}

$I I b^{119}$

In this laudatory poem, Van Godewijck addresses Andreas Colvius (1594-1671), honoring him in three distinct ways. First, he is described as a godly minister, spreading the message of Christ (vv. 1-6), after which she asks him to be favorable to her girlish verses (vv. 7-12). Then she addresses him as a distinguished cabinet owner, collecting the spoils from heaven, earth, and sea (vv. 13-24). What truly stands out, however, is Colvius' collection of shells (vv. 19-22); these are described with various metaphors: 'vacui penates,' 'picturatis limina tincta notis,' 'aula'. Finally, Colvius is hailed as the safeguard of the Latin school and the pride of Dordrecht (vv. 25-26).

118 Note that "ut" has the meaning of utinam. Alternatively, one could also read it as a conjunction elaborating on the previous line. The original period after "sonos" (v. 64) may then also be replaced by a comma.

119 Ms. 1025, p. 6-8. There also exists a Dutch poem by Van Godewijck on a gift of shells that she received from Andreas Colvius: Op de kinckhorens en Schulpen, die my d'Heer Colvius ver-eert heeft; see ms. 1024, p. 224. 
Ad clarissimum eruditissimumque virum D. Andream Colvium

Magne vir et semper Durdrechti gloria gentis, quo duce siderea pulpita luce micant,

saepe salutiferi doceas praeconia Christi, cum magna cura pendere res superum.

Promis caelestes fecundo pectore voces,

pandit et aethereos lingua diserta sonos.

Accipe, sed facili, iam nunc mea carmina, vultu, sunt pretii exigui virgineusque labor.

Longius a claris Musarum fontibus absum, longius a Cirrha Castaliisque vadis.

Sed honor est nobis Colvi dixisse salutem, ${ }^{120}$ si mea sunt vestra carmina tacta manu.

Oceani scrutator, naturae optime custos, quam nobis Oriens, Vespera dives, alit, quidque aether pandit, quid condit viscere terra, Tritonis spolium, capsula vestra tenet. Iam superos divosque tuas scrutaris in aedes,

1-2 Magne ... micant] cf. $\mathrm{CBP}^{2}, 122$ : "Magne vir, et Batavi celebris tutela lycei, / quo duce Palladiae floruit artis honos"; carm. IXb, 1-2; XVIb, 2 | 3-4 salutiferi ... superum] cf. $\mathrm{CBP}^{2}$, 124: "Laeta salutiferi docui praeconia Christi, / primaque res superum pendere cura fuit" | 6 pandit ... sonos] cf. $\mathrm{CBP}^{2}$, 115: "panderet aethereos lingua diserta sonos" 7-8 Accipe ... labor] cf. $\mathrm{CBP}^{2}, 122$ : "accipe sed facili Parnassia munera vultu / innocuumque tui protege vatis opus"; carm. IXb, 7-8 | 9-10 Longius ... vadis] cf. CBP2, 100: "Longius Aoniis quam vos a fontibus absum, / longius a Cirrha Castaliisque vadis" 11-12 Sed ... manu] cf. $\mathrm{CBP}^{2}$, 66: "Nec pudor est nobis regi dixisse salutem, / et mea sunt Caroli carmina tacta manu" | 14 quam ... alit] cf. $\mathrm{CBP}^{2}, 249$ : "quas Oriens vel quas Vespera dives alit" | 17-18 Iam ... vides] cf. $\mathrm{CBP}^{2}, 162$ : "iam superos divosque tuis scrutaris in hortis, / atque oculis coram numina picta vides"

17 tuas scrutaris in aedes intellegas tuis scrutaris in aedibus

120 Note that the word "sed" (naturally short) does not fit this hexameter; cf. VIIb, 6 
atque coram docto lumine rara vides. ${ }^{121}$

Exuvias animalis habes vacuosque penates, et picturatis limina tincta notis.

Quid nunc mirantur aurata palatia regum? ${ }^{122}$ splendidior spretis piscibus aula patet.

Omnia rara facis; metiris sidera, terram, et victi spoliis aetheris unus ovas.

Dordrechti vivas, celebris tutela lycei,

Palladii custos maxime et urbis honos.

19-20 Exuvias ... notis] cf. $\mathrm{CBP}^{2}, 215$ : "Exuvias animalis habes, vacuosque penates, / et picturatis limina tincta notis" | 22 splendidior ... patet] $\mathrm{cf}$. $\mathrm{CBP}^{2}, 216$ : "Splendidior spretis piscibus aula patet" | 23-24 Omnia ... ovas] cf. $\mathrm{CBP}^{2}, 415$ : "Omni arara facis, metiris sidera, terram / et victi spoliis aetheris unus ovas" | 25 celebris ... lycei] cf. CBP2 , 122: "Magne vir, et Batavi celebris tutela lycei"; carm. Xb, 19

18 lumine scripsi: lumina cod.

$I I I b^{123}$

Van Godewijck describes the arrival of the exiled Charles II in Dordrecht in May 1660, who was sailing from Breda to The Hague before he went

121 Together with the preceding line, these two are rather obscure. I interpret "superos divosque" and "rara" as referring to celestial spheres and unique astronomical phenomena, carefully observed by Colvius ("scrutaris"); on Colvius and his astronomical interest and knowledge, see D. van Miert, Humanism in an Age of Science. The Amsterdam Athenaeum in the Golden Age, 1632-1704 (Leiden - Boston, 2009), 265; BWN, vol. 3, 636. Note that the original manuscript reads "lumina", which I have tentatively emended to "lumine" ("with your learned eyes"; see apparatus), and that "coram" (used as an adverb here) is mistakenly used as an iamb.

122 Note the metrical productio ob caesuram of the word "mirantur" (cf., e.g., Verg. Buc. 10.69).

123 Ms. 1025 , p. 9-10. It seems very likely that Van Godewijck wrote this poem with the hope of publication in Lambert van den Bosch's supplement to either his De historie van sijn Majesteyt Karel de II (Dordrecht, 1660), or his Konincklijke beeltenis, ofte waerachtige historie van Karel de II (Dordrecht, 1661), which consisted exclusively of laudatory poems addressed to Charles II. Her threshold poem IVb was printed in the latter work, as well as a poem written in Dutch by Pieter van Godewijck. Whatever the reason was that caused poem IIIb to be omitted, it is yet another indication that Van Godewijck was occupied with disseminating her work through participation in the latest literary trends of the time. 
back to London. ${ }^{124}$ She compares him to the break of day ('Titan splendide'), hinting at the 'darker' period that has now come to an end, as he dispels the darkness, liberating the sky ('Olympum') (vv. 1-6). His arrival does not pass unnoticed; the Virgin of Dordrecht (a personification of the city) has spotted him, and commends all poets to sing (vv. 7-12). They do so, but unfortunately this poem does not suffice to capture this event (vv. 13-16).

In adventum serenissimi ac invictissimi principis Caroli II, Magnae Britanniae, Franciae et Hiberniae regis

Quid caelum stellis nobis splendentibus ardet, praeclara et, Titan splendide, luce venis?

Densas dispersit tenebras, absolvit Olympum, laetamque ostendunt mollia fata diem.

Lux tibi, lux nobis fulsit, Brittannia, Belgis:

Carolus exsurgit, qui mage sole micat.

Fama volatilis exclamat nunc laeta per urbes, regem expectatum sospitem adesse canit.

Quem Virgo Durdrechti muris cernit ab altis, et simul innumeras huc properare rates.

Voce omnes vates iucunda surgere iussit:

'ludito nunc laetis, fistula, carminibus.'

Protinus auditur Latiae facundia linguae,

Musa docet Batavae plectra movere lyrae.

Omnes cantabant iam laeto murmure vates;

quod nunc cantabo (pro dolor!) haud superest.

3 tenebras ... Olympum] cf. CBP, 40: "Lux clarior astris / emicat, et totum nebulis absolvit Olympum" | 13 latiae ... linguae] cf. CBP, 295: "Latiae facundia linguae / hoc ipso docet ore loqui" | $\mathbf{1 4}$ plectra ... lyrae] cf. $\mathrm{CBP}^{2}$, 70: "nec nisi Teutonicae plectra movere lyrae"; ibid., 495: "et Clariae discet plectra movere lyrae"

16 cantabo futurum ut vid. pro praesenti

124 Cf. H.H. Rowen, John de Witt, Grand Pensionary of Holland, 1625-1672 (Princeton, 1978), 442-443.

Humanistica Lovaniensia 70.2 (2021), 229-303 
$I V b^{125}$

Van Godewijck congratulates Lambert van den Bosch on his publication Konincklijcke beeltenis, ofte waerachtige historie van Karel de II. First, she likely refers to Van den Bosch's related epic Britannias of herstelde majesteyt, that appeared the same year ('Heroum') (vv. 1-2). Then she describes the content of the book: the death of Charles I and the preamble to the Restoration of Charles II in 1660 (vv. 3-7). She compliments Van den Bosch on his enterprise: the Stuarts of old will surely rejoice in his lively description of the Restoration (vv. 8-13). His name may be 'Sylvius' ('Forest-like'), yet his work is by no means 'silvestris,' that is, uncultured (v. 14).

In Historiam Restaurationis Caroli II, Magnae Britanniae, Franciae et Hiberniae Regis, a doctissimo viro Lamberto Sylvio descriptam

Vir praestans, quondam nobis funesta dedisti

Heroum audiri tua (pro dolor!) horrida fata.

Nunc Caroli mortem calamo, doctissime, pingis, infandum facinus nullo umquam tempore visum.

Nunc Caroli tibi stirps, magni genitoris imago, ${ }^{126}$

illustris pietatis apex, nam pectore in uno

virtutum coetus mire constantia condit.

Ad Tamesin ducis vento fremituque secundo,

6-7 illustris ... condit] cf. CBP, 39: "Illustris pietatis apex, cui pectore in uno / omnia nascentis regalia dona tiarae, / virtutemque choros caelestum cura recondit" $\mid \mathbf{8} \mathrm{Ad} \ldots$ secundo] cf. CBP, 39: "ad Tamesin molitur iter, fremituque secundo"

2 Heroum H Heroum cod. (sc. duplici littera capitali, ut impleretur illud spatium quod initio vacavisset neque typographia carmen elegiacum designaret | audiri: legi cod. | $\mathbf{3}$ calamo littera -a- altera in ras. cod. | 4 infandum: I Infandum cod. (item atque in v. 2) | 6 nam: nunc cod. $\mid \mathbf{7}$ virtutum mediae duae litterae -tu- s.s. cod. | coetus: choros cod.

125 Ms. 1025 , p. 11-12. In editing this poem, I have taken the printed version as the default; see Van den Bosch 1661 (as in n. 123), f. *5r-*5v. Differences with the ms. poem are noted in the apparatus.

126 The syntax of this line is unclear. I would argue that the intended meaning is very similar to vv. 3-4 and that the structure is elliptical. One could supply pingenda est, and read "tibi" as a dative of agent referring to Lambert van den Bosch. The ensuing clauses elaborate on "Caroli ... stirps". 
ostendis digitoque triumphans principis agmen.

Nunc gaudet vidisse diem quo prisca Stuarti

progenies magno decernit frena nepoti,

tergeminamque uno claudit sub Numine gentem.

Haec nunc gesta dabis fluida, dulcissime, penna;

Sylvius in libros haec non silvestria duxit.

10-12 Nunc ... gentem] cf. CBP, 39: "hunc gaudent nevisse diem, quo prisca Stuarti / progenies magno decernit frena nepoti, / tergeminamque uno claudit sub numine gentem"

$\mathbf{9}$ agmen: agẹmen a. ras. cod. | $\mathbf{1 0}$ gaudet fort. placet aut iuvat intellegendum | $\mathbf{1 4}$ haec: at cod.

$V b^{127}$

Van Godewijck honors the young William III, Prince of Orange (16501702), who began his studies in Leiden in 1659. She mentions his mother, Mary Henrietta Stuart, the recent 1660 Restoration of his uncle Charles II, and his resemblance to his father William II, who had died a week before his birth (vv. 1-6). She then compliments him on his poetic talent and his 'pietas' (vv. 7-12). Finally, she wishes that he, the glory of Holland, will continue growing and live happily (vv. 13-16).

In puerum principem Arausiorum Guilielmum III, cum Leydae studeret

Crescito, magne puer, sed sic quoque maxime princeps, optima spes matris, gloria Battaviae!

Delicium Caroli magni, qui sceptra potitus legitime domat ut sors violenta rapit.

Vivas in magnos, qui mire crescis, honores,

qui patrem ante annos, noster Iule, refers.

Agnoscit te Leida suum, te magnus Apollo

1-2 Crescito ... matris] cf. $\mathrm{CBP}^{2}, 226$ : "Nascere parve puer, non inficiande parenti, / nascere patris amor, nascere matris amor"; Mart. Epigr. 6.3.2 | $\mathbf{6}$ patrem ... refers] cf. CBP², 530: "Et patrem ante annos, noster Iule, refers" | 7-8 Agnoscit ... choros] cf. CBP2, 226: "Agnoscit te Leida suum, te magnus Apollo / vult etiam doctos inter habere locum"

127 Ms. 1025, p. 13-14.

Humanistica Lovaniensia 70.2 (2021), 229-303 
vult etiam doctos inter habere choros.

Natus es et Belgas inter Phoebumque deasque,

Castaliosque bibis, blanda iuventa, lacus.

Ipsa tibi iam nunc Pietas se pectore toto

abdit, et in tenero Gratia corde latet.

Guillelmus, spes nostra, vivat, lux maxima Belgis, ${ }^{128}$

Auriaci germen spiraque Battaviae!

Vivito nunc felix, annis iam crescito multis,

o civiumque decus deliciumque tuum! ${ }^{129}$

9-12 Natus ... latet] cf. $\mathrm{CBP}^{2}, 226$ : "Nasceris Aonides inter Phoebumque Deasque / Castalioque bibit caeca iuventa lacus. / Ipsa tuo iam nunc Pietas se pectore totam / abdit et in tenero Gratia corde latet"

10 Castaliosque littera -s- ultima s.s. cod. $\quad 11$ Pietas scripsi littera capitali: pietas cod. 16 tuum $s c$. tuorum

$V I b^{130}$

This poem addresses the students of the penultimate and antepenultimate grades at Dordrecht's Latin school. Van Godewijck recounts their performance of Hugo Grotius' Sophompaneas (referred to as 'Iosephi Historia'). ${ }^{131}$ Having greeted the youths as the glory of Dordrecht (vv. 1-4), she describes how the biblical story of Joseph and Benjamin moved her to tears (vv. 5-10). Finally, she expresses her hope that the excellent students will continue to perform plays in Latin and Greek (vv. 11-16).

Carmen ad secundae tertiaeque classis discipulos; cum Iosephi Historiam ab Hugone Grotio compositam, accurate et artificiose, me spectante agerent

128 Note that the word "vivat" does not fit the hexameter. Oddly, however, the word is used correctly in v. 5 and v. 15 .

129 Note the prosodically incorrect word "civiumque" (cf. VIIb, 3).

130 Ms. 1025, p. 15-16.

131 Hugo Grotius, Tragoedia Sophompaneas. Accesserunt, tragoedia ejusdem Christus patiens, et sacri argumenti alia, ex editione anni MDCXVII recusa emendatiora (Amsterdam, 1635 [USTC 1032354]). 
Palladii iuvenes, blandissima pectora Phoebi maturis annis, Castalidumque decus, ingenii dociles et dulcis cura parentum, et flores nitidi, gloria gymnasii:

Iosephum magnum concinna voce dedistis, maestitiam vidi laetitiamque simul.

Cum fratres fratris mulcebant genua palmis ${ }^{132}$ Iosephi, maeror magnus et altus erat; sed lacrimis quaesita madent Beniaminis ora, tunc etiam lacrimas eripuere mihi.

Egregii iuvenes, ad Olympum tendite gradus, ${ }^{133}$ tempore sed eritis nobilis urbis honos. ${ }^{134}$

Atque cothurnatos iam nobis edere versus pergite, sic calamo ludite carminibus.

Ludite, sed semper Latia Graiaque Camena: hoc iubet, hoc etiam quam iuvat ore loqui!

1 Palladii ... Phoebi] cf. $\mathrm{CBP}^{2}$, 69: "Palladii iuvenes, gratissima pectora Phoebo" 2 Castalidumque decus] cf. carm. XIb, 2

7 fratris: fratris. a. ras. cod. $1 \mathbf{1 2}$ sed aut intellegas et postpositivum aut fort. mutandum in sic

$V I I b^{135}$

In this poem, Van Godewijck addresses the marching seventh city guard (Dutch: burgervendel) of the Nieuwstraat ('Platea nova') in Dordrecht. At first, she wonders whether war has broken out, because of the martial display on the street (vv. 1-10). It turns out, however, to be the men from the neighborhood, who have gathered in a festive and ostentatious parade (vv. 11-14). Hopefully, it can remain mere play, and military glory will never come their way (vv. 15-18).

132 Note the prosodically incorrect word "genua".

133 Note that the word "gradus" does not fit the hexameter.

134 If the word "sed" is indeed what Van Godewijck intended, it is clear that she mistakenly thought that the vowel in it was naturally long; cf. IIb, 11.

135 Ms. 1025, p. 17-18. 
In cohortem septimam Plateae novae

An fallor, mediam Mavors nunc personat urbem, Bellona intrepide voce feroce sonat?

Cur rutilis armis splendent civiumque cohortes, ${ }^{136}$ magnifice fulgent vestibus Attalicis?

Vexillum auratum lateque ostendit in altum, aedes Hulsthouti splendidiore patent. ${ }^{137}$

Sclopos audivi forti clamore tonantes, Tartareae pariter sic sonuere tubae.

Vitrea quassabant resonantia murmure magno,pro dolor!- insuavis tunc mihi clangor erat.

Vicinae propter ridebant gesta virorum, Dalmanni coniux tunc hilaris modo erat. ${ }^{138}$

Magnifico graditur gressu dux ante cohortem ostendens Aiacem, aut Priamum rigidum.

Vicini lepidi, quam dulce est ludere bellum, armis iactari, tollere iam galeas!

Numquam cum hostibus opto vobis iungere tela, certe vestra equidem gloria inanis erit.

1-2 An ... sonat] cf. carm. XVIIIb, 1-2 | 8 sic ... tubae] cf. $\mathrm{CBP}^{2}$, 65: "Ingentes conticuere tubae"; carm Ib, 34; IXb, 12; XVIIb, 6

$\mathbf{2}$ feroce intellegas feroci $\mid \mathbf{5}$ ostendit $u$ t vid. reflexive intellegendum, quasi se ostendit | 6 splendidiore intellegas splendidius | $\mathbf{1 4}$ ostendens reflexive intellegendum, quasi se ostendens

\section{VIIIb $^{139}$}

This poem addresses the students of the top grade in Dordrecht's Latin school. Van Godewijck recounts their performance of Seneca's Troades and Phaedra (referred to as 'Hippolytus'). She mentions some of the main characters and how the performance would not have misfitted the theatres of ancient Rome (vv. 1-6). The boys declaimed with loud voices,

136 Note the prosodically incorrect word "civiumque" (cf. Vb, 16).

137 This is likely a reference to the merchant family [Van] Huls[t]hout, which dealt in textile.

138 I was unable to find any more information on the name "Dalmannus".

139 Ms. 1025, p. 19-21. 
yet the enactment was by no means excessive, boorish, or irreligious (vv.7-10). The atmosphere was truly classical and poetic, and the audience was under the spell of the play (vv. 11-16). Nymphs, but also she herself, will therefore always praise the youths, who succeeded in bringing the Muses to the theatre (vv. 17-22).

Ad praestantissimos eruditissimosque iuvenes, primae classis gymnasii Dordraceni auditores; cum Troadem et Hippolytum ex Seneca insigniter, me spectante, agerent

Cur graviter motu quassant ornata theatra?-

En tremit Hippolyti pulpita picta pede.

Hic Hecuba exsurgit suras iam vincta cothurnis, Andromachae alto nunc pondere syrma trahit.

Sic nunc gaudemus magnum spectasse theatrum, digna vel orchestris, magne Quirine, tuis.

Gymnasium clamor florens ad sidera tollit, nec tamen aut Bacchas, aut Athamanta sonat, non Veneris, non quae discet ludibria vana, sed gravis aut ingens, omnia plena Deo.

Exclamat Theseus infelix: 'ludite vates,' et fontes aperit Pegasus ipse suos.

Hic lyram pulsat magnus redivivus Apollo, ${ }^{140}$

2 pulpita ... pede] cf. DHA, f. C-r: "dum quatit Aschyleo [sic] pulpita picta pede" | 3-4 exsurgit ... trahit] cf. DHA, f. D4-r: "insurgit tragicis evinctus crura cothurnis, / Aeschyleumque aequo pondere Syrma trahit" | 5-6 Sic... tuis] cf. DHA, f. D4-v: "Longe alia, o, nostris iuvat exhibuisse theatris, / digna vel orchestris, magne Quirine, tuis" | 8-9 nec ... vana] cf. DHA, f. D4-r: "Non tamen hic epulas Terei, non saeva Thyestis / fercula, non Bacchas, non Athamanta sonat, / non Scyllas, non quae docuit ludibria vanus / Ennius, aut Enni, vanus et ipse, Nepos" | 12 fontes ... suos] cf. CBP2, 170: "Cur? Fontes aperit Pegasus ipse suos" | 13-14 Hic ... iocos] cf. IRD, f. 89v: "Gaudeo quod cythara ludat redivivus Apollo, / et priscos reparet docta Minerva iocos"

8 Bacchas: Ba.cchas a. ras. cod. $\mid$ comma post vocem sonat ego scripsi pro puncto | 9 Veneris intellegas Venerem | discet Batavismus (sc. 'leren'), ut vid., i.e. mendum ex usu linguae Batavicae cotidiano ortum; intellegas docet | $\mathbf{1 0}$ gravis intellegas grave (sc. rem gravem)

140 Note the prosodically incorrect word "lyram".

Humanistica Lovaniensia 70.2 (2021), 229-303 
et priscos reparat docta Minerva iocos.

Vocibus argutis vidi resilire theatrum

sublime, et lepidis cuncta sonare iocis.

Nunc sua cantabunt iam vobis carmina Nymphae, vobis carminibus iam celebrabo meis.

Assidue cantem: 'sapientes cedite vates, et remove lauros, Martia Roma, tuas.

Pieridum domus est, dominatur Phoebus in aula, Hic semper Musae regna beata tenent.'

15-16 vidi ... iocis] cf. IRD, f. 89v: "quam cum suavidicis video resilire theatrum / cantibus et lepidis cuncta sonare iocis" | $\mathbf{1 8}$ carminibus ... meis] cf. CBP2 $\mathrm{CB}^{2}$ 174: "praedia carminibus nunc celebranda meis"; carm. Ib, 8; Xb, 16 ] | 19-20 sapientes ... tuas] cf. DHP, 139: "Cedite Graiorum sapientes, cedite vates, / et remove lauros, Martia Roma, tuas" | 21 Pieridum ... aula] cf. DHP, 439: "Totaque Musarum domus est, hac laetus in aula / innocuos ducit, nec sine laude, dies" | 22 Musae ... tenent] cf. DHP, 439: "Heinsius illic / cum Phoebo et Musis regna beata tenet"

$I X b^{141}$

Van Godewijck honors Dordrecht's burgomaster Adriaan van Bleyenburg (1616-1682). He should disregard the poor quality of her verses, as they are created by a young woman's hand; it is she, who is knocking on his door, and not (yet) Anna Maria van Schurman, whose poetry is more eloquent and better known, or any other acclaimed poet (vv. 7-14). She can only hope that Van Bleyenburg will take some pleasure in reading her work; if so, this should be accredited to her diligent study (vv. 15-18). Hopefully, he will consider her poem not too bold; other poets may compose better verses, but no one is more sincere than her (vv. 19-22).

Ad amplissimum nobilissimumque virum consularem D. Adrianum Blyenburgium dominum de Naeldwyk

tit. amplissimum: A.mplissimum a. ras. cod. | nobilissimumque mediae duae litterae -sisubscr. cod. 
O patriae columen, Dordrechti gloria gentis!-

quo duce Palladiae iam viget artis honos,

qui veteres proavos claris virtutibus anteis,

et genus a prisca nobilitate trahis,

si vacat a gravibus, vir praestantissime, curis,

et liceat tecum nunc mea Musa loqui: ${ }^{142}$

iam $^{143}$, precor, accipe sed facili mea munera vultu, sunt pretii exigui virgineusque labor.

Sunt nondum nobis, fateor, regalia dona; vile tuis cogor far adolere focis.

Sum levior vates, nondum tua limina pulsat

1 Dordrechti ... gentis] cf. carm. IIb, 1 | 2-4 quo ... trahis] cf. CBP2, 122: "quo duce Palladiae floruit artis honos: / qui genus et proavos claris virtutibus anteis, / et laudem doctae nobilitatis habes"; carm. IIb, 2; XVIb, 2 | 5-8 si ... labor] cf. CBP², 67: "Si vacat a morbis nostras audire Camenas, / nec nimius medicam postulat aeger opem, / accipe, quae faciles scribunt tibi carmina divae, / nec mihi quae levis est, sit tibi Musa gravis"; ibid., 122: "accipe sed facili Parnassia munera vultu, innocuumque tui protege vatis opus"; carm. IIb, 7-8 | 10 vile ... focis] cf. $\mathrm{CBP}^{2}, 65$ : "vile tuis cogor far adolere focis" | 11 Sum ... vates] cf. $\mathrm{CBP}^{2}$, 191: "Sim levior vates"; carm. XVIIb, 5 | 11-12 nondum ... tubae] cf. CBP², 65: "Non tua Grotiades exul, non limina pulsat / Heinsius. Ingentes conticuere tubae"; carm. Ib, 34; VIIb, 8; XVIIb, 5-6

$\mathbf{1}$ gloria prima littera in ras. cod. | $\mathbf{6}$ mea Musa aut casus vocativi aut intellegas meae Musae (sc. casus dativi personae) | 8 virgineusque altera littera -i- in ras. cod. $\quad 11$ nondum secunda littera - n- s.s. cod.

142 There are at least three ways to interpret this line. The first option is to read "tecum" and "mea Musa" as addressing the Muse(s), whom Van Godewijck asks for inspiration. Another would be to take "tecum" and "mea Musa" as both referring to Blyeneburg, whom she acknowledges as a key figure for her poetry. The metaphoric usage of Musa as denoting a real-life person, however, is quite uncommon (for the classical period I could find only one precedent, Ov. Pont. 4.3.16; see ThLL, s.v., II.B.2 (= 1694 . 77-79)); moreover, I believe that this reading would be too intimate for this poem. The third option relies on the assumption that Van Godewijck misused the licet construction, putting "mea Musa" in a (classically non-existent) subject position, whereas it ought to have been an indirect object (sc. meae Musae). The word "tecum" again refers to Blyenburg, but "mea Musa" can now also metaphorically refer to Van Godewijck's poem itself (cf. ThLL, s.v., II.B.1 (= 1694. 40-77)), or to her poetic genius (ibid., II.A.1.a.ß.(1).(B) $(=1693$. 49-61)). In the light of the surrounding lines, this third reading seems most attractive to me; cf. also poem XIb, 3. I have therefore not added commas around "mea Musa", as they would force an apostrophic reading.

Humanistica Lovaniensia 70.2 (2021), 229-303 
Schurmanna, ingentes conticuere tubae.

Quin etiam superis placeant modo parva, nec illis semper inaurata victima fronte cadit.

Si tibi grata mei fuerit propensio mentis, hoc pretium studii grande putabo mei.

Si placeant elegi, nihil est quod plenius optem; iudicio siquidem stoque cadoque tuo.

Carmina (da veniam!) laxataque fibula linguae forte tibi nimium creditur esse loquax.

Te celebrent alii versu meliore poetae, pectore me nemo candidiore potest.

13-14 Quin ... cadit] cf. CBP2 , 65: "Quin et parva placent superis, modo casta; nec illis / semper inaurata victima fronte cadit" | $\mathbf{1 6 - 1 7}$ pretium ... elegi] cf. $\mathrm{CBP}^{2}$, 69: "atque aliquod pretium carminis esse puta. / Si placeant elegi, vates tibi iure placebit" | 19-20 laxataque ... loquax] cf. $\mathrm{CBP}^{2}$, 195: "Te praesente loquor, laxataque fibula linguae / forte tibi nimium creditur esse loquax"

15 mei intellegas meae | 17 plenius: melius a. ras. cod. | 19 Carmina (da veniam!) scripsi: Carmina da veniam cod.

$X b^{143}$

Van Godewijck expresses her gratitude to Arnoldus Senguerdius (16101677), who had sent her a letter with some precious gifts (vv. 1-10). She regrets that she is unable to give him anything in return (vv. 11-14). Instead, she presents him with her poetry as a gift; she will dedicate her verses to him (vv. 15-22). ${ }^{144}$

143 Ms. 1025, p. 24-26.

144 In this way, I also understand the rather obscure line "sacramus platanis barbita nostra tuis" (v. 18). The plane tree functions as a metaphor for Senguerdius' eminence. With its wide-spreading branches, this tree can be understood as overshadowing, but also as providing shelter (i.e. patronage) to Van Godewijck and her poetry. Another option would be to interpret this line as an allusion to Hor. Carm. 5.13-16 or V.T. Ps. 136.2 and its derived Dutch proverb (sc. "zijn lier aan de wilgen hangen"). The meaning would then be that Van Godewijck intends to end her poetic career (possibly as a humble gesture, acknowledging Senguerdius' superiority). This second reading, however, seems less congruous with the rest of the poem, and therefore most unlikely. 
Ad eminentissimum clarissimumque virum D. Arnoldum Senguerdium, in illustri Amstelodamensium schola academica philosophiae professorem primarium, bibliothecarium, scholarumque publicarum curatorem

Siccine selectas, gratissima munera, gemmas mittis et in chartis grandia dona tuis?

Munera dum tetigi, ac cera labente reclusi, credo mihi ingenuas erubuisse genas:

Baccas fulgentes, praeclara monilia vidi, mirabar mecum rarum opus aurificis

et dixi: 'non has dives mihi donat Hydaspes, sed bonitas Senguerdi officiosa mei.' 145

Per te dives ero, Pelopasque Midamque lacessam et strepet ad donum lingua diserta tuum.

Quas nunc persolvam pro tanto munere grates?oceani spoliis capsula nostra caret.

Sunt nondum nobis ingentes, Amstela, merces, nec procul Eoae hic inveniuntur opes.

Pro gemmis dabimus gratae tibi munera linguae,

1-2 Siccine ... tuis] cf. $\mathrm{CBP}^{2}, 162$ : "Siccine selectos, gratissima munera, flores / mittis et in bulbis numina clausa suis?" | $\mathbf{3}$ dum ... reclusi] cf. $\mathrm{CBP}^{2}, 159$ : "Venit, et ut tetigi, ac cera labente reclusi" | 4 ingenuas ... genas] cf. Ov. Her. 20.6 | 7-8 et ... mei] cf. CBP2 ${ }^{2}, 162$ : "Et dixi, non has dives mihi donat Hydaspes, / sed Tolli bonitas officiosa mei" | 9-10 Per ... tuum] cf. $\mathrm{CBP}^{2}$, 162: "Per te dives ero, Pelopasque Midamque lacessam. / Et strepet ad flores lingua diserta tuos" | $\mathbf{1 1}$ Quas ... grates] cf. ASO, 258: "Quas ego pro tanto persolvam munere grates?" | 13-14 Sunt ... opes] cf. CBP2 , 170: "si tecum Eoas mutat meus Amstela merces" | 15 Pro ... linguae] cf. GFP2 , 22: "Pro vitulis dabimus gratiae tibi munera linguae"

14 procul $u t$ vid. quasi adiectivum longinquae

145 Note the non-standard elision over the point of the mid-caesura of the pentameter (cf. Ib, 18).

Humanistica Lovaniensia 70.2 (2021), 229-303 
semper carminibus iam celebrabo meis.

Continuo tibi cantabo de pectore versus, sacramus platanis barbita nostra tuis.

Tu, vir magne, vale, et celebris tutela lycei, Musarum cultor, tu, decus Amsteliae.

Si desunt Musae, mihi tunc eris alter Apollo, te duce iam sequimur, te praeeunte canam.

16 carminibus ... meis] cf. $\mathrm{CBP}^{2}, 174$ : "praedia carminibus nunc celebranda meis"; carm. $\mathrm{Ib}, 8$; VIIIb, $18 \quad \mathbf{1 8}$ sacramus ... tuis] cf. $\mathrm{CBP}^{2}$, 117: "Sacramus foribus barbita nostra tuis"; V.T. Ps. 136.2; Hor. Carm. 5.13-16 | 19 vir ... lycei] cf. CBP2 , 122: "Magne vir, et Batavi celebris tutela lycei”; carm. IIb, 25

17 de scripsi: sed cod.

$X I b^{146}$

This poem, directed to the young François van der Burch (1643-1678), is probably a reply to a (lost) poem in which he had praised Van Godewijck's poetic talent. In her response, she first humbly asks him to stop extolling her Muse (vv. 1-12): cheap girls never ascend Mt. Helicon. Towards his poetry the Muse is far more favorable; she makes his renown equal to that of the ancient heroes (vv. 13-20). Finally, she mentions his noble father, Johan van der Burch (1612-1688), whose virtue has passed from father to son (vv. 21-22); surely, one day Van der Burch will prove indispensable for the Republic (vv. 23-24).

Ad praestantissimum nobilissimumque iuvenem, Franciscum vander Burgh

Grande decus iuvenum, Burgi clarissime vates, cultor Pieridum, Castalidumque decus, parce precor parvas ad sidera tollere Musas, parce, precor, studiis vota favere meis.

$\mathbf{1}$ Grande ... iuvenum] cf. CBP, 473: "Grande decus iuvenum, propera felicibus Euri" | 2 Castalidumque decus] cf. carm. VIb, 2 | 3-4 Parce ... meis] cf. CBP2, 101: "Parce precor graciles ad sidera tollere Musas, / nec studiis dona grandia verba meis" 
Scis, numquam viles scandunt Helicona puellae, non fert Parnassus virgineosque choros.

Nulla mihi suaves dictat Polyhymnia versus, nulla mihi sacram Musa propinat aquam.

Saepius adversa tentavi Pallade Pindum, et mihi, quae reliquis favit, iniqua fuit.

Carmina felices faciant, quis dexter Apollo pocula Pegaseis plena propinat aquis.

Musa tibi facilis meliori numine servit, cor magis augusto sueta replere Deo.

Illa tibi nullum passura poemata fatum dictat et a cunctis scripta probanda viris.

Illa tuos priscis titulos heroibus aequans, non sinet ingenii facta perire tui.

Tu Phoebi delubra moves, tu pectora vatum concutis et motu fervidiore rapis.

A magno genitore fluis; virtutibus heres nasceris, et digno semina patre trahis.

Tempus erit cum nostra tuis respublica curis crescet, et optabit te superesse sibi.

5 viles ... puellae] cf. CBP2, 71: “Cernitis, ut viles scandunt Helicona puellae?" | 7-8 Nulla ... aquam] cf. IZP, 58: "Nulla velut quondam dictat Polyhymnia versus, / nulla mihi sacram Musa propinat aquam" | 9-10 adversa ... fuit] cf. IZP, 57: "Scilicet adversa tentavi Pallade Pindum, / et mihi, quae reliquis favit, iniqua fuit" | 11-12 Carmina ... aquis] cf. IZP, 15: "Carmina felices faciant quis dexter Apollo / pocula Pegaseis plena propinat aquis" | 13-18 Musa ... tui] cf. IZP, 57: "Musa tibi facilis meliori numine servit, / cor magis augusto sueta replere Deo. / Illa tibi nullum passura poemata fatum / dictat, et a cunctis scripta probanda viris. / Illa tuos priscis titulos heroibus aequans / non sinet ingenii facta perire tui" | 19-20 Tu ... rapis] cf. $\mathrm{CBP}^{2}, 189$ : "Tu Phoebi delubra moves, tu pectora vatum / concutis, et motu fervidiore rapis" | 21-22 A magno ... trahis] cf. CBP2, 215: "A magno genitore fluis, virtutibus heres / nasceris, et digno semina patre trahis" | 23-24 Tempus ... sibi] cf. CBP2, 215: "Tempus erit, cum nostra tuis respublica curis / crescet, et optabit te superesse sibi"

$\mathbf{1 1}$ quis $s c$. quibus | $\mathbf{1 7}$ heroibus scripsi: Heroibus cod. | 22 patre scripsi: Patris cod. 
$X I I b^{147}$

Van Godewijck congratulates Lambert van den Bosch on his publication Britannias of herstelde majesteyt. First, she reminds us of an earlier poetic ('cantasti') work by Van den Bosch's, probably his Batavias of Batavische Aeneas (vv. 1-4). ${ }^{148}$ This time, however, his poetry deals with the history of Charles II (vv. 5-12). Nymphs will read it and reward him for his hard work (vv. 13-16). The glory of kings is nothing compared to that of the poet describing his deeds (vv. 17-18).

Ad clarissimum eruditissimumque virum, Lambertum Sylvium. Cum in lucem ederet Poema suum Heroicum

Quondam cantasti Belgae miracula terrae, Cattorumque arces, stemmata Battaviae, Teuthonumque urbes quondam coluisse Batavos, et pulsos nobis restituisse choros.

Ecce, renascentes surgunt nunc foedere Musae, et pulchro magnum carmine surgit opus.

Nunc Carolum extollis, sed regis maxima fata, proelia, fortunas, tempora, gesta notas.

Materies augusta tibi est, involvis et ostrum versibus, et regum sceptra superba canis.

Decurrunt gravibus regalia carmina dictis, erigis Aonias, numina clara, deas.

5-6 Ecce ... opus] cf. $\mathrm{CBP}^{2}$, 189: "Ecce, renascentes coeunt, ceu federe, Musae, / et vario pulchrum carmine surgit opus" | 8 proelia ... notas] cf. CBP², 189: "proelia, fortunas, tempora, gesta notas" | 9-10 Materies ... canis] cf. $\mathrm{CBP}^{2}, 66$ : "Materies augusta mihi est: involvimus ostrum / versibus, et regum sceptra superba cano"; carm. XIVb, 15 | 11 Decurrunt ... dictis] cf. $\mathrm{CBP}^{2}$, 250: "Decurrit gravibus regalis epistola dictis" | 12 erigis ... deas] cf. $\mathrm{CBP}^{2}$, 62: "erigis Aonias, numina lenta, Deas"

1 cantasti: cantast. a. ras. cod. | 9 Materies: Materia a. ras. cod.

147 Ms. 1025, p. 30-31. This poem appeared in print in Van den Bosch 1661 (as in n. 87).

148 Lambert van den Bosch, Batavias of Batavische Aeneas; spreeckende vande Hollantsche beginselen; op de wijse der oude en moderne Italiaensche poëten voorgestelt, en in VI boecken verdeelt [...] (Amsterdam, 1648 [USTC 1030381]). 
Naiades Batavae, veteris pia numina Rheni, saepe tuos numeros et tua scripta legent.

Et vario pictam nectent de flore corollam, quae pretium vestri dulce laboris erit. ${ }^{149}$

Quid fulgent sceptris reges? Haec gloria quanta esta te nunc regum sceptra deosque cani!

13-16 Naiades ... erit] cf. IZP, 67: "Naiades Batavae, veteris pia numina Rheni / sola meos numeros et mea scripta legen: / et vario forsan nectent de flore corollam / quae pretium nostri dulce laboris erit"; carm. XVIIb, 29-30 | 17-18 Quid ... cani] cf. CBP², 183: "Emineant sceptris reges. Haec gloria nostra est, / a nobis regum sceptra deosque cani"

13 Naiades altera littera -a- suprascr. cod.

$X I I I b^{150}$

This celebratory new-year poem (on the model of a genethliacon) is addressed to Pieter van Godewijck, and recounts the birth of Jesus, inaugurating the new year. Van Godewijck first dismisses the profane Muses and invokes Calliope, Muse of epic poetry and eloquence sometimes called the chief of the group, whom she asks to narrate the birth of Jesus (vv. 1-6). A lengthy description of this event follows, which is recounted as if it is happening in the present (vv. 7-26). The coldness and darkness of December are stressed (vv. 23-26), but Jesus' birth inaugurates the return of the sun, bringing new light ('diem') (vv. 27-28). The first of January has come, the 'holy month' ('sacro mense'; an Ovidian epithet; see apparatus); the 'Octave day' of the Nativity ('octava dies') has arrived (vv. 31-32). Van Godewijck then asks how she can show her gratitude to her father (v. 33). She wishes there will be many more happy new year's days for him, up until his death (vv. 34-40). Whatever happens, Christ will be his only hope (vv. 41-42).

149 Note that in Neo-Latin texts vester can function as the polite form of tuus.

150 Ms. 1025 , p. 32-35. 
In annum novum; ad reverendissimum charissimumque parentem meum D. Petrum Godevicium

Ite procul, celebres, Parnassi numina, Divae; ite procul studiis, Musa profana, meis.

Tu, Thymbraee, vale, divinae Palladis arces, non levet ipse meam Castalis unda sitim.

Tu mihi, Calliope, dicito, sanctissima, partus ${ }^{151}$ virginis et pueri tempora prima Dei.

Nascitur optato Messias tempore Christus, nascitur extincta vivida morte salus.

Talia gaviso memorantes nuntia mundo, angelico resonant carmina blanda sono.

Annua iam nati redeunt sollemnia Christi, nunc redeat tanto vindice parta Salus.

In caelis residens in terris vagit utrumque, de genitore Deus, de genitrice puer.

puer est magnus, Deus est, et virginis infans, euge, at nobis est filius ille datus!

1-2 Ite ... meis] cf. $\mathrm{CBP}^{2}$, 46: "Ite procul veteres, Parnassia numina, Musae: / ite procul studiis turba profana meis" | 4 non ... sitim] cf. $\mathrm{CBP}^{2}$, 46: "Cyrrha vale, Phoebique domus, non Castalis amnis, / non levat ipsa meam Phocidos unda sitim" | 5-6 Tu ... Dei] cf. $\mathrm{CBP}^{2}$, 46: "Tu mihi virgineos aperi sanctissima partus / Calliope, et pueri tempora prima Dei” | 7-10 Nascitur ... sono] cf. ISP2, f. B7-v: "Nascitur optato Messias tempore Christus, / nascitur extincta vivida morte salus. / Talia gaviso memorantes nuntia mundo, / angelici resonant carmina blanda soni" | 11 Annua ... Christi] cf. GFP², 183: "Annua iam nati redeunt sollemnia Christi" | $\mathbf{1 2}$ redeat ... salus] cf. $\mathrm{CBP}^{2}, 47$ : "et redeat tanto vindice parta Salus" | 13-14 In ... puer] cf. $\mathrm{GFP}^{2}, 210$ : "In caelis residens, in terris vagit: utrumque, / de genitore Deus, de genetrice puer" | 15 Deus ... infans] cf. GFP ${ }^{2}, 209$ : "Filius iste Dei, Deus est, et virginis infans" | 16 nobis ... datus] cf. GFP2 209: "nobis / hic puer est, nobis filius ille datus"

1 Parnassi scripsi: Pernassi cod. $\mid 2$ Musa profana $u t$ vid. singularis pro plurali numero 9 Talia: T.alia $a$. ras. cod. | memorantes ut vid. intellegendum quasi memorantia (sc. cum voce carmina cogruens) | mundum loco inter memorantes et nuntia (sc. per dittographiam) a. ras. cod. $\mid \mathbf{1 5}$ sed ut vid. nihil significat, sed metri causa insertum

151 This intended hexameter is prosodically incorrect. Van Godewijck likely believed that the first vowel in the fourth word "dicito" was short. 
Non ebur est lectus; non sunt holoserica vestes, sed tenuem panni fasciolaeque tegunt.

Vix habet ipse caput tenerum quo ponat, habetque imperium in terras, aequor, et astra tamen.

Hospitium lustra, mitem circumspice matrem, et genitum brumae tempore cerne Deum.

En, horret gelidus brumali nocte December, frigore stant amnes vinctaque terra gelu est.

Non color est silvis, non est sua gratia campis; haec faciem noctis tempora mortis habent.

Sed vertit rapidum caelo sol aureus orbem, optatumque novum reddit ab axe diem.

Iam cadit in Iani mira ratione Kalendas, pulsus et a sacro mense December abit.

Ecce, octava dies quam rite per omnia quadrat! Inchoat haec annum, prima quod orta, novum.

Quid tibi nunc, pater o mi dilectissime, reddam?

Saepius ut redeat iam precor iste dies, ut novus optatis tibi cursibus exeat annus, per sua decurrens candidus astra precor.

Et divina tuae praestet solacia menti, rebus et incolumem te sinat esse tuis, donec in occursum Christi rapiaris amantis, corpore destructo mens animata fide.

17-18 Non ... tegunt] cf. GFP2, 209: "Non ebur est lectus; non sunt holoserica vestes, / sed tenuem panni fasciolaeque tegunt" | 19-22 Vix ... Deum] cf. GFP2, 209: "Vix habet ipse caput tenerum quo ponat, habetque / imperium in terras, aequor, et astra tamen. / Hospitium lustra, mitem circumspice matrem, / et genitum brumae tempore cerne Deum" 23-28 En ... diem] cf. GFP 2 , 210: "En horret gelidus brumali nocte December, / frigore stant amnes, vinctaque terra gelu est. / Non color est silvis, non est sua gratia campis, / haec faciem noctis tempora, mortis habent; / sed vertit rapidum caelo sol aureus orbem, / optatumque novo reddit ab axe diem" | $\mathbf{3 0}$ pulsus ... abit] cf. Ov. Pont. 4.4.24 | 31 octava dies] cf. Corippus, In laudem Iustini 4.90

$\mathbf{2 2}$ cerne: cern. a. ras. cod. $\mid \mathbf{3 3}$ dulc loco inter mi et dilectissime a. ras. cod. $\mid \mathbf{3 7}$ divina scripsi: divinae cod. 
Quidquid erit tandem, tua spes est unica Christus, haec tibi perpetuo dulce levamen erit.

Filia tua carissima,

Margareta Godewyk. 1662.

41 Quidquid ... Christus] cf. ISP, f. B4-v: "Quidquid erit tandem, mea spes est unica Christus"

\section{$X I V b^{152}$}

Van Godewijck congratulates Lambert van den Bosch on his publication Sacrum melos, of kerck-geheymenis (referred to as 'Poemata Sacra'). At first she wonders whether the Muse is singing because of this new work ('docto divinas carmine laudes'), or because of Van den Bosch's earlier heroic epics ('Heroum'), such as Batavias of Batavische Aeneas (vv. 1-2). The next passage, with its rather obscure first distich, opens a description of the work: a new, heavenly, and godly poet (sc. Van den Bosch) praises God's great works made for the sake of men and his glory (vv. 3-10). Finally, the poet addresses Van den Bosch more directly in the second person: his work truly facilitates one's spiritual development (vv. 11-16). He should therefore continue his good work (vv. 17-18).

In Poemata Sacra clarissimi eruditissimique viri Lamberti Silvii

$$
\begin{gathered}
\text { Aut celebrat docto divinas carmine laudes, } \\
\text { aut memor Heroum nomina Musa canit. } \\
\text { Iam novus exoriens sed non sine Numine vates } \\
\text { Uranius magnas carmine laudat opes, } \\
\text { aeternumque bonum, patrii regna aurea caeli, }
\end{gathered}
$$

5-10 Aeternumque ... Deum] cf. ISP², f. M2: “Aeternumque bonum, patrii regna aurea caeli, / adflictis animis nuntiat iste liber. / Felix qui cupida bona talia concipit aure, / semper et infracto corde recepta tenet. / Illum perpetuo numen caeleste fovebit, / praesentem vivat laetus ut ante Deum"

2 Heroum scripsi: heroum cod. $\quad \mathbf{3}$ sed ut vid. nihil significat, sed metri causa insertum; cf. carm. XVb, 17 n. 37$),$ f. $* 7$ r.

152 Ms. 1025, p. 36-37. This poem was published in Van den Bosch 1662 (as in Humanistica Lovaniensia 70.2 (2021), 229-303 
afflictis animis nuntiat iste liber.

Felix, qui cupida bona talia concipit aure,

semper et infracto corde recepta tenet.

Illum perpetuo Numen caeleste fovebit, praesentem vivat laetus ut ante Deum.

Et iucunda tua exercet meditatio mentem, seu lux seu gelidae tempora noctis eant.

Te vate aethereas animo iuvat ire per arces, quaeque minus possum cernere, mente sequi.

Materies augusta tibi est divina canendi,

per quam maiestas conspicienda Dei est.

Perge igitur studiis ascendere talibus astra;

quam cupis, in terris gloria parta tibi est.

15 Materies ... est] cf. CBP 2 , 66: "Materies augusta mihi est"; carm. XIIb, 9

7 concipit invenitur in carmine edito: consipit cod.

$X V b^{153}$

In this poem, Van Godewijck commemorates her father's seventieth birthday. She is happy that they can celebrate this day in February ('caeli sub piscibus'), and hopes he will live longer than Nestor of old (vv. 1-6). She then describes him as an honorable man, who has dedicated forty years of his life to educating the boys at the local Latin school (vv. 7-10). The fruits of his work are evidenced by the success of his former students, who can be found everywhere (vv. 11-16). She stresses the fact that he has lived peacefully; teaching grammar was his main concern (vv. 1720). Finally, she promises to dedicate her poetry to him and his age, until he will celebrate his birthday in heaven (vv. 21-24).

In diem natalem reverendissimi carissimique parentis mei, D. Petri Godevici, iam septuagesimo anno agente

Splendet natalis tuus, o pater optime, mensis, contingit nobis hunc celebrare diem. 
Dum fervent calidae caeli sub piscibus ollae, natalis retulit festa colenda tui.

Vive, precor, Pyliaeque dies transcende senectae,

et placido superum munere perge frui.

Mens tranquilla tibi est nec grandis conscia culpae, pectore sincero nomina pacis amas.

Lustra octo assidue sudasti in Palladis arces, discipulorum a te spargitur ampla seges.

Consul discipulus fuit et grandisque senator, a te, quae loquitur verba, iuventus habet. ${ }^{154}$

Discipulos patria omnis habet, per rura, per urbes cernis iam curae publica signa tuae.

Qua graderis documenta tui fructumque laboris vides et ingenii fulgida signa tui. ${ }^{155}$

Ferme denis septem sed sine litibus annis vixisti, ac semper mens tua fraude caret.

\begin{abstract}
3 fervent ... ollae] cf. CBP2, 507: "En fervent calidae caeli sub piscibus ollae" | 4 natalis ... tui] cf. IZP, 28: "natalis retulit festa colenda tui"; cf. carm. XVIIb, 10 | 5-7 Vive ... culpae] cf. $\mathrm{CBP}^{2}$, 198: "Vive precor, Pyliaeque dies transcende senectae, / et placido superum munere perge frui. / Mens tranquilla tibi est, nec grandis conscia culpae" | 8 nomina ... amas] cf. $\mathrm{CBP}^{2}$, 221: "Iam pia, sed tutae, nomina pacis amat"; carm. Ib, 30 | 10 discipulorum ... seges] cf. $\mathrm{CBP}^{2}, 244$ : “doctorum per te spargitur ampla seges" | 11-12 Consul ... habet] cf. $\mathrm{CBP}^{2}, 244$ : "Dux tuus est, consul tuus est, grandisque senator, / a te quae loquitur verba professor habet" | 13-16 Discipulos ... tui] cf. $\mathrm{CBP}^{2}, 244$ : "Discipulos patria omnis habet. Per rura, per urbes / doctorum per te spargitur ampla seges. / Qua graderis, documenta tui fructumque laboris / adspicis, et curae publica signa tuae" | 16 ingenii ... tui] cf. $\mathrm{CBP}^{2}, 228$ : "Ingeniique, senex, fulgida signa tui"
\end{abstract}

17 sed $u t$ vid. nihil significat, sed metri causa insertum; cf. carm. XIVb, 3

154 Note that "iuventus" does not fit the pentameter, as its ultimate syllable is naturally long.

155 Van Godewijck rather unfortunately changed the word "adspicis" from Barlaeus' original line (see apparatus) to "vides", which does not fit in the first foot of the pentameter. 
Non odio tua fama labat nec displicis ullo; ${ }^{156}$ volvere grammaticam maxima cura fuit.

Nunc tibi, care pater, cantabo gutture versus, sacramus et annis carmina laeta tuis, ${ }^{157}$

donec inoffensae transacto tempore vitae natalem supera sede beatus agas.

Haec gratulabunda cecinit filia tua carissima, Margareta Godewyk

$\mathbf{1 9}$ Non ... labat] cf. $\mathrm{CBP}^{2}$, 198: "Non odio tua fama labat, servitque favori" | $\mathbf{2 4}$ natalem ... agas] cf. GFP2 ${ }^{2}, 384$ : "in supera vitam sede beatus agit"

19 displicis intellegas displices | ullo fort. ulli intellegas | 21 gutture scripsi: guttere cod. | 23 inoffensae scripsi: in offensae cod.

$X V I b^{158}$

In this poem, Van Godewijck consoles Arnoldus Senguerdius on the premature death of his son Wilhelmus (1648-1663). First, she hails him as the pride of Amsterdam, where he held the position of professor of philosophy (vv. 1-2). In accordance with the genre rules of the 'consolatio,' she then asks him to stop weeping: there were many other great men from the Dutch Republic, such as Gerardus Vossius, who lost their sons during their lifetime (vv. 3-8). He should also realize that his son was mortal; Senguerdius has paid his debts, as his son belonged to God, who has now rightfully claimed him back (vv. 9-14). He should stop crying, assured that his son is safely in heaven, where he is looking down on our miserable human affairs (vv. 15-26).

156 Van Godewijck likely thought that the verb displicere belonged to the third conjugation, not the second. Theoretically, the form "displicis" does indeed fit the hexameter, whereas the correct form "displices" would not.

157 This prosody in this intended pentameter is incorrect.

158 Ms. 1025, p. 41-43.

Humanistica Lovaniensia 70.2 (2021), 229-303 
Super obitu ornatissimi doctissimique iuvenis Wilhelmi Arnoldi Senguerdii, philosophiae omnisque politioris litteraturae cultoris assidui, die Maii 1663 praemature exstincti. Ad celeberrimum virum D.M. Arnoldum Senguerdium, patrem

Magne vir et Batavis clarum decus addite terris, quo duce Amsteliae floruit artis honos, ${ }^{159}$

pone modum lacrimis: nimium plorare recusat, cui pietas lacrimas sufficit ipsa suas.

Iam tibi magnanimi praestant solacia patres, docta quibus soboles occidit ante diem.

Iam sua praelustres ostendunt funera Vossi, Et praematura pignora rapta manu.

Fles natum genitor; luges, sed dedolet ille, mortalem qui se scit genuisse sibi.

Non periit tuus ille, ac reddis, nomina solvis, quique tuus fuerat, plus erat ille Dei.

Non reperit propere sua qui, non nostra, reposcit, Non reperit propere qui moritura rapit.

1 Magne ... terris] cf. $\mathrm{CBP}^{2}$, 113: "Maxime vir, patriis clarum decus addite terris" | 2 quo ... honos] cf. $\mathrm{CBP}^{2}$, 122: "quo duce Palladiae floruit artis honos"; carm. IIb, 2; IXb, 2 | 34 Pone ... suas] cf. $\mathrm{CBP}^{2}$, 113: "pone modum lacrimis. Nimium plorare recusat / cui pietas lacrimas sufficit ipsa suas" | 5-8 Iam ... manu] cf. $\mathrm{CBP}^{2}, 182$ : "Iam tibi Scaligeri donant solacia patres, / docta quibus soboles occidit ante diem. / Iam sua praelustres obiectant funera Douzae / et praematura pignora rapta manu" | 9 Fles ... genitor] cf. CBP ${ }^{2}, 113$ : "Fles natum genitor" | 9-10 sed ... sibi] cf. $\mathrm{CBP}^{2}, 113$ : "Qui genuit, dolet extinctum. Sed dedolet ille / mortalem qui se scit genuisse sibi" | 11-14 reddis ... rapit] cf. $\mathrm{CBP}^{2}, 114$ : "Debitor es. Sobolem cum reddis, nomina solvis. / Quique tuus fuerat, plus erat ille Dei. / Non repetit propere, sua qui, non nostra, reposcit. / Non repetit propere, qui moritura rapit"

tit. litteraturae: Littạratura a. ras. cod. | $\mathbf{2}$ vocem iam post Amsteliae del. | 11 comma post reddis ego inserui; ut vid. intellegendum est sobolem cum reddis, nomina solvis, ut scriptum in $C B P^{2}, 114 \mid \mathbf{1 2}$ quique scripsi: Cuique cod. 
Siste tuas lacrimas sublime tenet Olympum ${ }^{160}$ altumque et vultu spendidiore nitet.

Securum nunc astra tenent: formidinis expers peccandi didicit dedidicisse modum.

Iam castos inter coetus animasque piorum fulgidus aeternae munera pacis habet.

Laetus in Elysia ripa spatiatur amoenus, semper ubi vitreas lucus inumbrat aquas.

Non nitidum glacialis hiems constringit Olympum, quassa nec immiti grandine tecta sonant.

Perpetuum ver astra colunt, ubi tutus inanes

nunc hominum curas regnaque vana videt.

16 et ... nitet] cf. $\mathrm{CBP}^{2}$, 223: "Borbonii tactus radiis, iam tangeris astris / altior, et vultu splendidiore nites" | 17-18 Securum ... modum] cf. CBP2, 115: "Securum nunc astra tenent. Formidinis expers, / peccandi didicit dedidicisse modum" | 19-26 castos ... videt] cf. ICM, 148-149: "Tu castos inter coetus animasque piorum / fulgidus aeternae munera pacis habes. / Laetus in Elysia ripa spatiaris, amoenus / semper ubi vitreos lucus inumbrat aquas. / Non nitidum glacialis hiems constringit Olympum / quassa nec immiti grandine tecta sonant. / Perpetuum ver astra colunt, ubi tutus inanes / nunc hominum curas regnaque vana vides"

15 sublime fort. intellegas sublimem | tenet loco inter tenet et Olympum (sc. per dittographiam) a. ras. cod. | $\mathbf{2 6}$ curas scripsi: cura cod. | vana: van a.c. cod.

\section{161}

Van Godewijck congratulates Wolferdus Senguerdius (1646-1724), son of Arnoldus Senguerdius (see Xb, XVIb), on his birthday. She begins with praising his poetic talent, after which she asks him to be favorable to her poem, composed on the banks of the Merwede ('ad Mervae undas'); she is only a minor poet, knocking on his door. More renowned poets,

160 Note that the word "tenet" does not fit the hexameter (it was arguably intended to function as a trochee), although it occurs correctly in v. 17. Moreover, it seems as if "sublime" should be read as modifying "Olympum", in which case the correct form would be sublimem (see apparatus). This could, of course, be a copying error, yet in the light of Van Godewijck's other grammatical mistakes, I have chosen to regard this as the more authentic reading.

161 Ms. 1025, p. 44-46.

Humanistica Lovaniensia 70.2 (2021), 229-303 
like Joan Blasius (1639-1672), are not yet paying him a visit (vv. 1-8; cf. $\mathrm{IXb}, 11-12)$. Then she celebrates the day Wolferdus was born in Utrecht, recounting the words that Lachesis, the goddess of Fate, would have used to predict his promising future to his parents (vv. 9-18). Indeed, he now truly resembles his noble father (vv. 19-20). She hopes that Wolferdus will gain the favor of the most mighty men and live a long life, not neglecting poetry (vv. 21-26). Finally, she asks the Muses to honor Wolferdus; she herself, however, will be the first to do so (vv. 27-30).

In natalem doctissimi iuvenis Wolferdi Senguerdii

Optima Senguerdi soboles, cui ubera Pallas ${ }^{162}$ dedit, et e Clariis praebuit hausta vadis, ${ }^{163}$

accipe quae liquidas ad Mervae scribimus undas carmina, amicitiae pignora certa meae.

Sum levior vates, tua nondum limina tangit

Blasius; ingentes conticuere tubae.

Et quae rara venit, forsan tibi Musa placebit, scriptoris novitas non leve pondus habet.

Nunc ludi celebres atque annua festa coluntur, natalis apparuit festa colenda tui. ${ }^{164}$

1-2 Optima ... dedit] cf. IZP, 28: "Fulgenti soboles non infitianda Minervae, / ubera cui puero diva Thalia dedit" | $\mathbf{2}$ e clariis ... vadis] cf. IZP, 57: "poculaque e Clariis praebuit hausta vadis" | 3-4 Accipe ... meae] cf. IZP, 4: "Accipe quae liquidas ad Lisae flevimus undas / carmine fortunae conveniente meae" | 5 Sum ... vates] cf. $\mathrm{CBP}^{2}$, 191: "Sim levior vates"; carm. IXb, 11 | 5-6 nondum ... tubae] cf. CBP2 , 65: "Non tua Grotiades exul, non limina pulsat / Heinsius. Ingentes conticuere tubae"; carm. Ib, 34; VIIb, 8; IXb, 11-12 | 78 Et ... habet] cf. $\mathrm{CBP}^{2}, 65$ : "Et quae rara venit, potius tibi Musa placebit: / scriptoris novitas non leve pondus habet" | $\mathbf{1 0}$ natalis ... tui] cf. IZP, 28: "natalis retulit festa colenda tui"; carm. XVb, 4

162 Note the hiatus in "cui ubera".

163 "Dedit" is aberrant from the point of view of the prosody.

164 The first half of this intended pentameter is heavily unbalanced: neither "natalis" nor "apparuit" fits the meter. 
Iam, precor, iste dies fausto tibi sidere fulsit, ${ }^{165}$

Traiecti dum te protulit alma parens.

Ludite, Pierides, nam me meminisse iuvabit quod Lachesis dixit, talia verba patri:

'hic Senguerdus erit; clari gaudete penates!

Haec soboles priscos mascula reddit avos.

Hic heres virtutis erit; non alter Iulus

Amsteliae poterat conspicuum esse decus.'

Ut faciem Patris ingenium Wolferdus adumbrat, et dignum tali se probat esse viro!

Sic virtute tua regum mereare favorem, et ducibus placeas principibusque viris.

Vive diu felix, atque utere dulciter annis, labraque Pegaseis prolue semper aquis,

ut tibi contingat dulces coniungere Musas, et vitae comites semper habere deas.

Cingite, Pierides, iuvenem, pia turba, poetam, ambiat implicitum myrtus odora caput.

Ante deas omnes nectam de flore corollam, quae pretium vestri dulce laboris erit.

13 meminisse iuvabit] cf. Verg. Aen. 1.203 | 14-17 Quod ... erit] cf. CBP², 489: "dicitur haec Lachesis verba locuta patri: / hic Bickerus erit, clari gaudete penates, / haec soboles priscos mascula reddet avos. / Hic heres virtutis erit" | 23-24 Vive ... aquis] cf. NBP, 119: "Vive diu felix atque utere dulciter annis, / labraque Pegaseis prolue semper aquis" 27-28 Cingite ... caput] cf. NBP, 44: "Cingite Pierides iuvenum pia turba poetam, / ambiat implicitum myrtus odora caput" | 29-30 Ante ... erit] cf. IZP, 67: "et vario forsan nectent de flore corollam / quae pretium nostri dulce laboris erit"; NBP, 49: "Ante deos omnes verno de flore coronam / crinibus imponam Cypria diva tuis"; ibid., 100: "hoc pretium teneri dulce laboris erat"; carm. XIIb, 15-16

11 commata circa precor ego inserui | 12 protulit: p..p... a. ras. cod. | 15-18 signa orationis rectae meo arbitrio induxi | $\mathbf{1 8}$ poterat conspicuum in ras. cod | $\mathbf{2 4}$ comma post vocem aquis ego posui pro puncto

165 The commas around "precor" are editorial and support an interjectional reading of the word. Alternatively, one could read it as the main verb to which the predicate "fulsit" is subordinated. In the this case, however, the subjunctive (fulserit) would normally be required in classical Latin.

Humanistica Lovaniensia 70.2 (2021), 229-303 


\section{$X$ IIIIb $^{166}$}

This poem addresses the students of Dordrecht's Latin school. Van Godewijck recounts how they performed Seneca's Agamemnon and Medea with much display at the theatre ('aulam Palladis') (vv. 1-4). Performing the Agamemnon is not an easy task. Yet the boys succeeded well in enacting both Clytaemnestra's ('Tyndaridem') murder of her husband Agamemnon (vv. 5-8), and Medea's character (vv. 9-10). Their play evoked the atmosphere of ancient Roman tragic drama (vv. 11-12), but comedy was also performed (vv. 13-16). Van Godewijck ends by encouraging the young men to continue climbing Mt. Helicon (i.e. performing tragedy and comedy) and enjoy the proximity of Apollo (vv. 17-18); the Muse will grant them honor (vv. 19-20).

Ad praestantissimos eruditissimosque iuvenes, gymnasii Dordraceni auditores, cum Agamemnonem et Medeam ex Seneca me spectante agerent

Nunc Seneca in mediam, non fallor, personat aulam

Palladis, et graviter pulpita picta sonant.

Prodiit in lucem violenta tragoedia rursus, scaena gravis fulget vestibus Attalicis.

Ardua materia est, tenui nec tuta Camenae, reddere magnorum tristia facta ducum.

Tyndaridam cerno stillantem sanguine regis; heu, flemus lacrimis horrida fata viri.

Sed Medea altis prodit saltata cothurnis:

quis oculos possit, quis satiare animum?

Aurea Romanae redierunt tempora nobis, antiquis tragicis nunc suus extat honos.

1-2 Nunc ... sonant] cf. carm. VIIb, 1-2 | 5 Ardua ... Camenae] cf. IZP, 25: "Ardua materia est, tenui nec tuta Camenae" | 11-12 Aurea ... honos] cf. NBP, 44: "Aurea Saturni redierunt tempora nobis, / vatibus antiquus nunc suus extat honos"

$\mathbf{1}$ fallor s.s. cod. $\mathbf{1 1}$ Romanae ut metrice conveniat, tamen syntactice legas Romana 
Interea surgit lepido Comoedia vultu nixa pedem socco, cetera serpit humi.

Risimus hanc omnes, omnes risere Camenae, et vobis palmam diva Thalia dedit.

Scandite nunc, iuvenes, super ardua culmina montis, et frueris Phoebo nunc propiore deo.

At vobis titulos et honos nunc Musa reservat, Musa dabit patrio semper honore frui.

13-14 lepido ... humi] cf. DHP, 169: "At festiva sedet lepido Comoedia vultu / nixa pedem socco, cetera serpit humi" | 16 diva ... dedit] cf. IZP, 28: "ubera cui puero diva Thalia dedit"

13 Comoedia scripsi littera capitali: comoedia cod. | punctum post vultu del. | 18 frueris fort. fruimini intellegas | 19 At ut vid. nihil significat, sed metri causa insertum | honos ut metrice conveniat, tamen syntactice intellegendum honorem

$X I X b^{167}$

This poem is perhaps not so much about Van Godewijck's study ('Museum') as it is about her. This room embodies a really safe space where she spends countless hours, separated from the vanities of the outside world (vv. 1-4). In her study, she serves God (vv. 5-6), freed from worries and other affections, in what is probably an allusion to the Stoic concept of 'ataraxia' (vv. 7-12).

In Museum meum

Hic mea tuta domus, mea moenia, praedia, turres, laeta quies; si me quaeritis, hic habito.

Contenta hic vivo et vanum contemnor honorem, nec mundo aut magnis servio divitiis.

Servio iam Domino qui clara morte redemit,

me in Christo pono spemque fidemque meam.

$\mathbf{3}$ contemnor intellegas contemno | $5 \mathrm{~m}$. loco inter qui et clara a. ras. cod. | $\mathbf{6}$ Me in scripsi: me In (sc. littera capitali in secunda voce, me serius adscripto ut vid.) cod.

167 Ibid., p. 49.

Humanistica Lovaniensia 70.2 (2021), 229-303 
Numquam me excrucio meditando incommoda vitae, non animum temere triste dolore coquo.

Nam multos perimit mens nescia cedere fatis, ante diem canos anxia cura facit.

Sum contenta meis, sum nondum obnoxia curis; mens mea tum dici iure beata potest.

7-8 excrucio ... coquo] cf. ISP2, f. I-r: "Ne te ipsum excrucias meditando incommoda vitae? / Nec temere nimio corda dolore coquas" 9 multos ... fatis] cf. ISP'2, f. I-r: "Heu, perimit multos mens nescia cedere curis" | 10-12 ante ... potest] cf. ISP ${ }^{2}$, f. I-r: "ante diem canos anxia cura facit. / Mens contenta suo, mens non obnoxia curis / vivit, et haec dici iure beata potest"

$\mathbf{8}$ triste intellegas tristi | $\mathbf{1 1}$ meis: mea a. ras. cod.

$X X b^{168}$

In this poem, Van Godewijck expounds on her motto 'Deus mihi vicus' (see also the introduction to poem Ia); Christ will be her safe ward as long as she lives (vv. 1-6).

In nomen meum

Vicus Christus erit dum Spiritus hos regit artus, dum flabunt venti vicus amoenus erit.

Est mihi vicus Christus solus dum aethera fulgent, dum stabit mundus dulce levamen erit.

Est mihi vicus fixus in omni tempore Christus,tempore sit cuncto spes mea fixa tibi.

Margarita Godewyck

Deus mihi vicus

$\mathbf{1}$ dum ... artus] cf. Verg. Aen. 4.336 | 3 aethera] cf. ad peculiarem numerum pluralem Ven. 3.9.7 
$X X I b^{169}$

Van Godewijck congratulates Matthijs Balen on his publication 'Beschryvinge der stad Dordrecht' (referred to as 'Dordrechti Descriptionem'). She starts off with an a fortiori argument: if by rescuing the fatherland one deserves a crown, what then does Balen deserve, who built it? (vv. 1-2). He is the pride of Dordrecht and the Muses, and deserves eternal renown (vv. 3-4).

In Dordrechti Descriptionem a viro clarissimo Matthia Balen accurate editam

Qui patriam servat meruit gestare coronam; quid Balen meruit, qui patriam aedificat?

Delicium, Dordrechta, tuum, laus prima Camenae; is pretium famae non morientis habet.

3 Delicium ... tuum] cf. CBP2, 221: "Delicium, Durdrechta, tuum" | laus ... Camenae] cf. $\mathrm{CBP}^{2}$, 209: "Vondeli, Batavae decus et laus prima Camenae" | $\mathbf{4}$ pretium ... habet] cf. $\mathrm{CBP}^{2}, 216$ : "et pretium famae non morientis habet"

2 Quid Balen: BALEN quid invenitur in libro edito

$X X I I b^{170}$

In this posthumously published poem, Van Godewijck congratulates Dirck van Bleyswijck on his publication 'Beschryvinge der stadt Delft' (referred to as 'Delphi Descriptionem'). First, she addresses the readers and draws their attention to Van Bleyswijck's great work (vv. 1-2). She then hints at his political career; the citizens of Delft can rightfully rejoice in Van Bleyswijck, who glorifies his native land in his writings and is such a good ruler over Delft's inhabitants (vv. 3-4).

169 Ibid., p. 51. This poem was published in Balen 1677 (as in n. 2), f. **r [sic].

170 Ibid., p. 52. This poem was published in Van Bleyswijck 1681 (as in n. 31), 886. 
In Delphi Descriptionem a nobiliss. clarissimoque D.D. Theodoro a Bleyswyk, I.C. consulari apud Delphenses viro descriptam

Cernite praeclaro calamo depingere Delphin; moenia, fata, duces, parva papyrus habet.

Qui patriam celebrat, iusto moderamine flectit, sub tali merito consule civis ovat.

2 parva ... habet] cf. $\mathrm{CBP}^{2}, 167$ : "et faciem mundi parva papyrus habet" | $\mathbf{4}$ consule ... ovat] cf. $\mathrm{CBP}^{2}, 220$ : "Et quater hoc uno consule civis ovat"

tit. consulari ... viro: Viro apud Delfenses Consulari invenitur in libro edito | 1 Delphin: Delphum invenitur in libro edito

Utrecht University Aron.ouwerkerk@gmail.com 


\section{Figures}

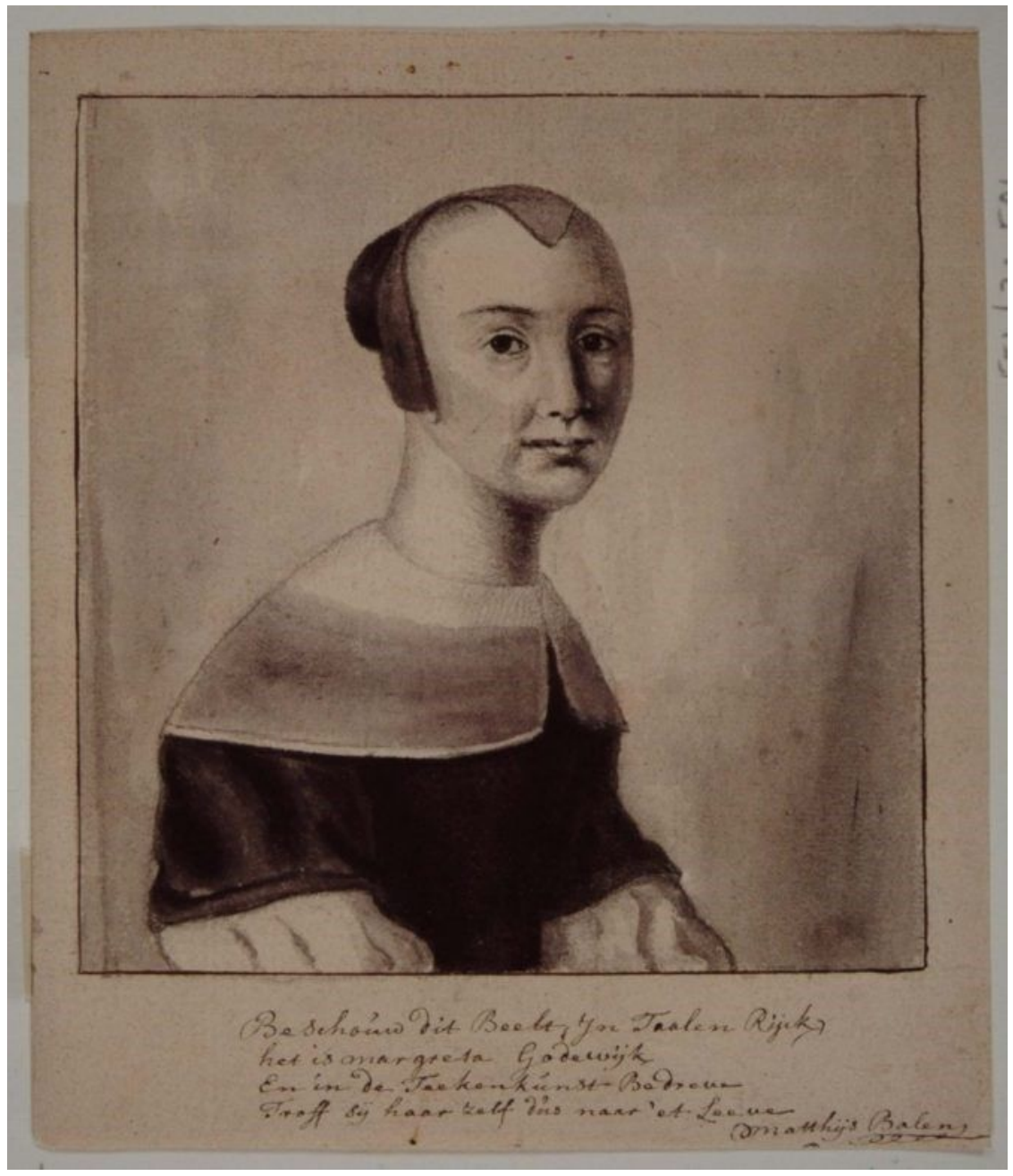

Fig. 1: Self-portrait by Margareta van Godewijck [s.a.]. Indian ink on paper; $13 \times 12.6 \mathrm{~cm}$. The caption is authored by Matthijs Jansz Balen: "Beschouw dit beelt, in taalen rijck, / Het is Margreta Godewijk, / En in de teekenkunst bedreven, / Troff sij haar zelf dus naar 'et leeven" ("Behold this image, rich in languages, / It is Margreta Godewijck, / And skilled in draftsmanship, / She drew herself true to nature"). RAD, ms., Collectie Dordracum Illustratum, no. 551_30501.

Humanistica Lovaniensia 70.2 (2021), 229-303 